\title{
Üretim Süreçlerinde Ergonomik Riskler ve Risk Değerlendirme Yöntemleri: Cıvata Fabrikasında Bir Uygulama*
}

\author{
Sami Sever ${ }^{1 * *}$, Mustafa Deste ${ }^{2}$ \\ 1 İnönü Üniversitesi, İktisadi ve İdari Bilimler Fakültesi, İşletme Bölümü, Malatya, Türkiye, (ORCID: 0000-0001-6827-054X), sami.sever@inonu.edu.tr \\ 2 İnönü Üniversitesi, İktisadi ve İdari Bilimler Fakültesi, İşletme Bölümü, Malatya, Türkiye, (ORCID: 0000-0001-5781-6543), mustafa.deste@ inonu.edu.tr
}

(İlk Geliş Tarihi 7 Mart 2021 ve Kabul Tarihi 26 Haziran 2021)

(DOI: $10.31590 /$ ejosat.892538)

ATIF/REFERENCE: Sever S. \& Deste, M. (2021). Üretim Süreçlerinde Ergonomik Riskler ve Risk Değerlendirme Yöntemleri: Civata Fabrikasında Bir Uygulama. European Journal of Science and Technology, (25), 417-441.

\section{Öz}

Günümüzde insan üretim faktörlerinin en önemli parçası konumundadır. Bu nedenle, insanın işe işin insana uyumunu amaçlayan ergonomi üretim süreçlerinde verimliliğin artırılmasında önemli bir rol üstlenmektedir. Özellikle emek yoğun işletmelerde, ergonomik faktörlerin dikkate alınmaması, çalışan verimliliğini olumsuz etkilemekle birlikte çalışanlarda kalıcı mesleki hastalıklara sebep olabilmektedir. Bu çerçevede işletmelerde ergonomik risklerin ortadan kaldırılması, çalışanların performans ve verimlilikleri üzerinde son derece önemlidir.

$\mathrm{Bu}$ çalışmada, bir işletmede ergonomik risk değerlendirme yöntemleri kullanılarak süreçlerin analiz edilmesi ve çözüm önerilerinin sunulması amaçlanmıştır. Bu kapsamda Malatya 2. Organize Sanayiinde bağlantı elemanları sektöründe faaliyet gösteren bir fabrika uygulama yeri olarak seçilmiştir. Cıvata üretimi yapan fabrikada ana süreçlerden birisi olan tel çekme bölümü çalışmanın odak noktasını oluşturmuştur. Bu çerçevede öncelikle bölüm sorumlusu ve çalışanlarla derinlemesine mülakatlarla mevcut durum analizi gerçekleştirilmiş, yerleşim planı detaylı bir şekilde incelenmiş, fabrika ortamında aksiyon kameraları ile farklı açılardan, çeşitli zamanlarda yaklaşık 36 saat süreyle süreçlerin görüntü kaydı yapılmış ve tel çekiminde kullanılan makinelerin detaylı iş akış şemaları oluşturulmuştur. Çalışanların duruş pozisyonlarına ilişkin açı değerleri Dartfish paket programı yardımıyla hesaplanmıştır. Elde edilen veriler çerçevesinde tel çekme bölümünde çalışan işçilerin kas ve iskelet sistemlerinde zorlanmalara neden olabilecek 55 süreç literatürde sıkça kullanılan REBA, RULA ve QEC yöntemleri aracılığıyla analiz edilmiştir.

Yapılan analiz sonucunda özellikle kalın çapta tel çekimi yapan makinedeki görevlerin büyük çoğunluğunun çok yüksek risk ve yüksek risk grubunda yer aldığı tespit edilmiştir. Ergonomik açıdan riskli olduğu tespit edilen görevler için iyileştirme önerileri sunulmuştur.

Anahtar Kelimeler: Ergonomi, Ergonomik Risk, Ergonomik Risk Değerlendirme.

\section{Ergonomic Risks And Risk Assessment Methods in Production Processes: An Application in The Bolt Factory}

\begin{abstract}
Today, it is the most important part of human production factors. For this reason, ergonomics plays an important role, aiming the harmony of work to people and people to work. Especially in labor-intensive businesses, neglecting ergonomic factors negatively affects employee productivity and causes permanent occupational diseases in employees. In this context, the elimination of ergonomic risks in the enterprises is extremely important on the performance and productivity of the employees.
\end{abstract}

\footnotetext{
* $\mathrm{Bu}$ çalışma, İnönü Üniversitesi Sosyal Bilimler Enstitüsü İşletme Ana Bilim Dalı'nda "Üretim Süreçlerinde Ergonomik Riskler ve Risk Değerlendirme Yöntemleri: Cıvata Fabrikasında Bir Uygulama” başlıklı yüksek lisans tezinden türetilmiştir. Söz konusu tez İnönü Üniversitesi Bilimsel Araştırmalar Projeleri Birimi tarafından 2019-1771 proje numarası ile desteklenmiştir.
} 
In this study, it is aimed to analyze processes and offer solutions by using ergonomic risk assessment methods in an enterprise. In this context, a factory operating in the fasteners sector in Malatya 2nd Organized Industry was chosen as a place of application. Wire drawing section, which is one of the main processes in the factory that produces bolts, was the focal point of the study. In this framework, the current situation analysis was carried out primarily with in-depth interviews with department managers and employees, the layout plan was examined in detail, the process was recorded for approximately 36 hours at various times with action cameras in factory environment and detailed work flow charts of the machines used in wire drawing were created. Angle values of the employees' posture positions were calculated with the help of Dartfish package program. Within the framework of all these data, 55 processes that can cause difficulties in the muscle and skeletal systems of the wire drawing department have been analyzed through REBA, RULA and QEC methods, which are frequently used in the literature.

As a result of the analysis, it was determined that the vast majority of the tasks in the machine, especially those with thick wire drawing, are in the very high risk and high risk group. Improvement recommendations for tasks found to be ergonomically risky have been presented

Keywords: Ergonomic, Ergonomic Risk, Assessement of Ergonomic Risk.

\section{Giriș}

Teknolojik gelişmeler gün geçtikçe üretim süreçlerindeki makine ve robot kullanımını artırmaktadır. Fakat üretim süreçlerinde teknoloji kullanımı hangi düzeyde olursa olsun insan, üretim sürecinin önemli bir bileşenidir. Bununla birlikte Türkiye'de teknolojik gelişmelerin sanayiye yansımaları yavaş olmaktadır. $\mathrm{Bu}$ nedenle imalat sektöründe faaliyet gösteren birçok işletmede iş gücüne dayalı üretim yöntemleri kullanılmaktadır. Emeğin yoğun olduğu işletmelerde, ergonomik faktörlerin dikkate alınmaması, çalışan verimliliğini olumsuz etkilemekte ve çalışanlarda kalıcı mesleki hastalıklara sebep olabilmektedir. Çalışma ortamının fiziki koşulları, ekipmanın niteliği, iş istasyonlarının düzeni, iş yerinin işçi sağlı̆̆ ve güvenliği açısından durumu, çalışanın verimliliğini doğrudan etkilemektedir. Fabrikalarda iyileştirilmeye açı, fakat ergonomik açıdan detaylı bir inceleme yapılmadığından tespit edilemeyen birçok nokta var olabilmektedir. Bu noktaların tespit edilerek iyileştirilmesi sonucunda çalışanla çalışma ortamı arasındaki uyum ve iş yerindeki verimlilik artırılabilmektedir.

Ergonomi uygulamalarının verimliliğe etkisinin içerisinde iş kazalarının önlenmesi de yer almaktadır. Kazaların şiddeti ne ölçüde olursa olsun çalışanlar ve çalışan yakınları bu tür durumlarda psikolojik veya fizyolojik olarak olumsuz etkilenebilmektedir. Fabrika ortamında meydana gelen iş kazaları, işlerin aksamasına, diğer çalışanların moral ve motivasyonlarının azalmasına neden olabilmektedir. Ayrıca iş verenler açısından da önemli maddi kayıplarla sonuçlanabilmektedir. Yaşanan iş kazaları sonucunda bireysel ve toplumsal olarak maddi-manevi büyük kayıpların oluşması ergonominin bu alandaki katkısını daha da değerli kılmaktadır.

Bütün bunlar düşünüldüğünde işletmelerde ergonomik risklerin ortadan kaldırılmasının, çalışanların performansları ve verimlilikleri üzerinde önemli bir role sahip olduğu anlaşılmaktadır (Grossmeier, Mangen, Terry ve HaglundHowieson, 2015). Yalnızca bu risklerin belirlenebilmesi ve ortadan kaldırılabilmesi işletmeler açısından kolay bir süreç değildir. Literatürde yer alan yöntemlerin kullanılması için faaliyetlerin tek tek incelenerek analiz edilmesi gerekmektedir. $\mathrm{Bu}$ da uzun bir gözlem süreciyle ve detaylı bir çalışmayla olabilecek bir durumdur. Bu çalışmada söz konusu fabrika için farklı risk değerlendirme yöntemleri kullanılarak çalışanlar üzerindeki ergonomik riskler belirlenmiş ve çözüm önerileri geliştirilmiştir.

Araştırma kapsamında, Malatya 2. Organize sanayinde cıvata imalatı yapan bir fabrikada tel çekme bölümündeki çalışanlarda kas ve iskelet zorlanmasına sebep olan süreçleri, ergonomik risk değerlendirme yöntemleri aracılığıyla incelemek, ergonomik açıdan riskli uygulamaları belirlemek ve bu uygulamaların iyileştirilmesine yönelik öneriler sunmak çalışmanın ana amaçları arasında yer almaktadır.

Çalışmanın ilk bölümünde ergonomi kavramı için yapılan tanımlamalara, ergonomi kavramının tarihsel gelişimine, ergonominin gelişiminde pay sahibi olan çalışmalara, ergonominin çeşitlerine ve ana hatlarıyla üretim süreçlerindeki ergonomik risklerin neler olduğuna yer verilmiştir. Literatürde yer alan farklı kategorilerdeki ergonomik risk değerlendirme yöntemlerine ilişkin genel bilgiler ve çalışmanın uygulama kısmında kullanılan REBA, RULA ve QEC yöntemleri hakkında detaylı bilgiler sonraki bölümde verilmiştir. Çalışmanın devam eden bölümünde ergonomik risk analizi uygulaması başlığı altında çalışmanın amacı, önemi ve kapsamına değinilerek sektör ve fabrika hakkında genel bilgilere, mevcut durum analizine, risklerin belirlenmesine ve iyileştirme önerilerine yer verilmiştir. Son bölümde ise ulaşılan sonuçlar detaylı bir şekilde ele alınmıştır.

\section{2. İşletmelerinde Ergonomi ve Üretim Süreçlerinde Ergonomik Riskler}

Ergonomi, insanların karmaşık sistemlerdeki rolüne, insan kullanımına yönelik ekipman ve tesislerin tasarımına, çevresel konforun ve güvenliğin geliştirilmesine odaklanmaktadır. Dolayısıyla ergonomi işletmelerin tesis yerleşim planından, ürününün son tüketiciye ulaşıncaya kadar olan bütün süreçlerinde az veya çok yer alabilmektedir. Ergonomi uygulamalarını bünyesinde barındıran işletmeler etkinlik, verimlilik gibi çeşitli yararlar sağlayarak günümüz rekabet ortamında avantajlı konumda yer alabilmektedirler. Ergonomi uygulamaları ürün tasarımına, üretime veya çalışana yönelik olmak üzere üç farklı şekilde gerçekleştirilebilmektedir. Ürün tasarımına yönelik olduğunda, ergonomin temel işlevi ürünü daha kullanışlı kılmaktır. Daha kullanışlı bir ürün ise işletmenin müşteri memnuniyetini ve diğer faktörlere bağlı olarak pazar payını artırabilmektedir. Ürün tasarımının aksine, üretime yönelik olduğunda çalışanların güvenliği ve sağlığının yanı sıra, şirketin verimliliğini, kalitesini ve karlılığını artıracak süreci tasarlamakla ilgilenmektedir. Çalışana yönelik olduğunda ise ergonomi uygulamalarının temel hedefi, çalışanın sağlık ve güvenliği olmaktadır. Özellikle imalat işletmelerinde üretim süreçlerine yönelik ergonomi uygulamalarında en büyük hedef kaliteyi, verimliliği ve karlılığı artırmaktır (Karwowski ve Gavriel, 1998).

Bir işin yapılması esnasında öngörülen veya öngörülmeyen, bilinen veya bilinmeyen birtakım riskler ve tehlikeler vardır. Söz konusu riskler ve tehlikeler, çevre, işçi, üretim ve üretim araçları için tehdit unsurudur. Ortaya çıktığında da telafisi mümkün 
olmayan sonuçlar doğurabilir www.ekart.com.tr (05.11.2019). Çalışanlarda kas ve iskelet sistemi rahatsızlığına sebep olabilecek ergonomik riskler şunlardır (Esen ve Fiğlali, 2013):

- Çalışma istasyonlarının düzensiz yerleşimi,

- Uygun olmayan araç ve ekipman,

- Tekrarlanan işler,

- Mola yetersizliği,

- İşin hızı,

- Çalışma ortamının çevresel durumu (sıcaklık, nem, aydınlatma, titreşim),

- Yüksek güç talebi,

- Organizasyon yetersizliği,

- Zaman baskisı,

- Çalışanın fiziksel kapasitesi.

\section{1. Üretim Süreçlerinde Ergonomik Riskler}

Üretim süreçlerindeki ergonomik riskler, işletme ve çalışanlar açısından olmak üzere ikiye ayrılmaktadır.

\subsection{1. İşletme Açısından Riskler}

İşletme açısından oluşabilecek riskleri, iş gücü kaybı, sağlık ve iş gücü masraflarında artış, verimlilik ve kalite düşüşü şeklinde ifade etmek mümkündür.

İş gücü kaybı açısından bakıldığında, işletmeler için değer yaratan faktörlerin başında iş gücünün geldiği ve işletmelerin başarı ve başarısızlığında önemli bir role sahip olduğu bilinmektedir. İş gücü, emek faktörünün üretim faaliyetlerine katılan toplamı olarak tanımlanmaktadır. Bir işletmede iş gören herkes iş gücü kapsamında değerlendirilmektedir. İş gören ise bilgi ve becerilerini örgütsel hedefler doğrultusunda kullanan ve işletmede istihdam edilen kişilerden oluşmaktadır (Öztürk ve Akbulut, 2011). Çeşitli sebeplerle çalışanların bu bilgi ve becerilerini işletme planları çerçevesinde kullanmaması veya çalışanların sorumluluklarındaki işleri yerine getirememeleri, iş gücü kaybı olarak ifade edilmektedir. SGK'nın devamsızlık verilerine göre Türkiye'de iş kazası ve meslek hastalıkları nedeniyle iş gücü kaybının 2017 yılında 3.996.895 gün olduğu görülmektedir (SGK, 2019). Bir iş görenin herhangi bir sebeple devamsızlık yapması durumunda o iş diğer çalışanlar tarafindan yapılmaktadır. Bu durum diğer çalışanların iş yükünü artırmakta ve onlara ekstra ücret ödenmesine neden olabilmektedir (Küçük, Özbek ve Küçük, 2015). Türkiye geneline bakıldığında iş gücü kaybı nedeniyle işletmelerin maliyetlerinin önemli miktarda arttığını ifade etmek mümkündür. Literatür incelendiğinde iş gücü kaybının çeşitli nedenleri olduğu görülmektedir. Olumsuz algılanan çalışma ortamı koşulları, iş kazaları, meslek hastalıkları vb. nedenlerle işletmelerde iş gücü kaybının yaşandığı görülmektedir.

İmalat işletmelerinde çalışanların yaptığı hareketleri ve harcadığı çabayı azaltmaya yönelik çeşitli istasyonlar tasarlanmakta ve çeşitli makinalar kullanılmaktadır. Ancak iş istasyonlarındaki makinelerin sayıca az veya işlevlerinin yetersiz olması durumunda işçiler yüksek oranda bedensel güç kullanabilmektedir. Ergonomiyi göz ardı ederek tasarlanan iş istasyonları ise genellikle çalışanlar için uygunsuz vücut duruşu ve aktiviteleri gerektirebilmektedir. Bu tür durumlar, çalışanların yaralanmasına veya mesleki kas rahatsızlığı yaşamalarına sebep olabilmektedir. Çalışanların iş yerlerinde yaşadıkları kazalar ve mesleki rahatsızlıklar ise tedavi masrafları ve yüksek tazminat maliyetleri ile sonuçlanabilmektedir (Li, Gül ve Al-Hussein, 2019). Öte yandan işletmeler, mesleki rahatsızlık ve yaralanma sebebiyle işe devam edemeyen çalışanların yerine yeni veya geçici personel istihdam ettiklerinde, yeni personele verilecek eğitimle ilgili maliyetlerle de karşı karşıya kalabilmektedir.

Verimlilik ve kalite açısından bakıldığında, işletmelerin küresel rekabet ortamında hayatta kalabilmeleri için verimliliklerini sürekli olarak artırmak durumunda oldukları herkes tarafından bilinmektedir. Verimlilik en basit şekilde üretim miktarı(çıktı)/üretim faktörleri miktarı(girdi) ile ifade edilmektedir. Üretim süreçlerindeki ergonomik riskler, verimlilik üzerinde girdi miktarını artıcı çıktı miktarını ise azaltıcı bir etkiye sahiptir. Çünkü yapılan araştırmalar iş gücünde yaşanacak \%1'lik bir kaybın, üretim seviyesinde \%2,5'luk bir düşüşe denen olduğunu göstermektedir ( Eronat, 2004; Akt. Küçük vd., 2015). Ergonomi ve kalite arasındaki ilişkiyi ortaya koymak için İsveç’te otomobil fabrikasında yapılan bir araştırmada ergonomik problemin olduğu işletmelerdeki kalite ile ergonomik problemin olmadığı işlerdeki kalite arasında üç kat fark olduğu ve kalite düşüklüğüne neden olan işlerin başında montajı zor olan işlerin yer aldığı belirtilmiştir (Eklund, 1995).

\subsection{2. Çalışanlar Açısından Riskler}

Çalışanlar açısından oluşabilecek riskleri, iş veriminde düşüş, yaşam kalitesinde düşüş ve sağlık problemlerinde artış şeklinde ifade etmek mümkündür.

İşletmeler açısından riskler kısmında ele alınan verimlilik kavramı aynı zamanda çalışanları da ilgilendirmektedir. Çünkü işletmenin genel verimliliği çalışanların verimliliğine bağlı olarak şekillenmektedir. Sağlık riskinin çalışanların üretkenliği üzerindeki etkisi bazı araştırmacılar tarafından incelenmiştir. Yapılan araştırma sonuçlarında, yüksek sağlık riskinin düşük iş verimliliğine neden olduğu ortaya konulmuştur (Boles, Pelletier ve Lynch, 2004; Burton, Conti, Chen, Schultz ve Edington, 1999; Grossmeier, Mangen, Terry ve Haglund-Howieson, 2015; Riedel, Lynch, Baase, Hymel ve Peterson, 2001). Tablo 1 işçi sağlığına yönelik iyileştirme girişimlerinin, kısa ve uzun vadeli kurumsal üretkenliği nasıl etkilediğini göstermektedir. Çalışanların verimliliği üzerine etkisi olan sağlık risklerinin başka bir deyişle ergonomik risk faktörlerinin işletmeler açısından oldukça önemli olduğu anlaşılmaktadır. 


\begin{tabular}{llll}
\hline Girişimler & Sonuçlar & Nihai Çıktılar \\
\hline $\begin{array}{l}\text { Hastalıkları̈ Önlenmesi, Sağlı̆̆ın } \\
\text { Geliştirilmesi }\end{array}$ & Azalan Devamsızlık & Artan Verimlilik \\
\hline Akut ve Kronik Hastalık Yönetimi & $\begin{array}{l}\text { Gelişmiş Performans, Yaratıcılık, } \\
\text { Motivasyon }\end{array}$ & Azalan Maliyet \\
\hline Çevre Sağlığı ve Güvenliği & Azalan Kazalar, Maliyet Tasarrufu & \\
\hline Sağlıklı Kurum Kültürü & Azalan Sağlık Bakım Maliyetleri & \\
\hline
\end{tabular}

Çalışanın yaşam kalitesinde düşüş, çalışanlar için oldukça önemli bir risk unsurudur. Yaşam kalitesi kavramı literatüre, 1948 yılında Dünya Sağlık Örgütü (DSÖ)'nün sağlığ1 tanımlamasından sonra girmiştir. DSÖ sağlığı, herhangi bir hastalığın veya sakatlığın olmamasıyla birlikte fiziksel, zihinsel ve sosyal açıdan iyi olunması olarak tanımlamıştır. Bu iyi olma halinin ölçülmesi için yapılan çalışmalarda, yaşam kalitesi kavramı giderek önemli hale gelmiştir (Testa ve Simonson, 1996). Yaşam kalitesi, insanların içinde bulundukları kültür ve değer sisteminde kendilerini algılayış şeklidir. Yaşam kalitesi, insanların inançlarını, etrafındakilerle olan sosyal ilişkilerini, fiziksel ve psikolojik durumunu kapsayan çok boyutlu bir kavramdır (Avcı ve Pala, 2004). Yaşam kalitesi kavramına fabrika çalışanları özelinde bakıldığında, çalışma koşulları, çalışma ortamı ve çalışma ilişkileri yaşam kalitesi için temel belirleyiciler olarak değerlendirilmektedir. Çalışanların etrafını çevreleyen bu unsurlar, çalışanların yaşam kalitesini doğrudan etkilemektedir. Çalışma ortamında bulunan ve çalışanın sağlığını etkileyebilecek başlıca risk etmenleri; sıcaklık, gürültü, gazlar, metaller, kimyasallar, ağır kaldırma, tekrarlanan hareketler, itme-çekme, dönme gibi hareketler olarak sayılabilir. Çalışanın bu risk etmenlerinden biri veya birkaçına maruz kalması durumunda sağlık sorunları başlamakta ve yaşam kalitesi olumsuz yönde etkilenmektedir (Uskun, Öztürk, Kişioğlu ve Sönmez, 2015).

Çalışanlar, yaptıkları işe bağlı olarak çeşitli sağlık problemleri ile karşı karşıya kalabilmektedirler. Karşılaşılan sağlık problemleri, iş kaynaklı veya çalışan kaynaklı olabilmektedir. Tekrarlı hareketler, yük kaldırma, titreşim, gürültü, taşıma ve uzun süreli aynı pozisyonlar iş kaynaklı; kondisyon yetersizliği, dikkat eksikliği, sigara kullanımı, yaşlanma ve aşırı kilo ise çalışan kaynaklı sağlık problemlerine neden olan başlica etmenlerdir (Özcan ve Kesiktaş, 2007). En yaygın meslek hastalıkları bel, omuz ve boyun çevresinde, üst ve alt ekstremiterde görülmektedir. Karşılaşılan bu hastalıklar erken, orta ve ileri olmak üzere üç evreye ayrılmaktadır (Bilir, 2007):

- $\quad$ Erken evre hastalıkları: Çalışma esnasında ortaya çıkan ağrı ve yorulmalardır, performansı etkilemez, dinlenince geçmektedir.

- Orta evre hastalıkları: İşin başlangıcında görülen ağrı ve yorgunluk halidir, gece boyu sürmekte ve tekrarlanan işlerde performans düşüklüğüne neden olmaktadır.

- İleri evre hastalıkları: Aşırı derecede ağrı ve yorulmalar görülmektedir. Dinlenince geçmeyen bu ağrılar uykuya engel olmakta ve performansin ciddi oranda azalmasına neden olmaktadir.
Yapılan araştırmalar, ergonomi eğitiminin ve ergonomik iyileştirmelerin iş gücü kaybını, sigorta tazminat ödemelerini, meslek hastalıklarının sıklığını ve sebep olduğu maliyetleri azalttığını, iş memnuniyeti, yaşam kalitesini verimliliği, yatırımların geri dönüş hızını artırdığını göstermektedir (Amell ve Kumar, 2001; Bernacki, Guidera, Schaefer, Lavin ve Tsai, 1999; Foye, Cianca ve Prather, 2002; Silverstein ve Clark, 2004).

\section{Ergonomik Risk Değerlendirme Yöntemleri}

Teknolojik ilerlemeyle birlikte çalışanlar üzerindeki fiziksel iş yükü azalmasına rağmen, sanayi bakımından geri kalmış ülkelerde daha fazla olmak suretiyle gelişmekte olan ve hatta gelişmiş ülkelerde bile çalışanların mesleki görevlerini yerine getirmeye bağlı olarak kas ve iskelet sistemi rahatsızlıkları yaşadıkları görülebilmektedir. $\mathrm{Bu}$ durum bazı ekonomik kayıları beraberinde getirerek bireyleri, örgütleri ve en nihayetinde tüm ülkeyi olumsuz yönde etkilemektedir (Özel ve Çetik, 2010). Yapılan araştırmalar, kas ve iskelet sistemi rahatsızlıklarının önlenmesinin tedavi sürecinden daha az maliyetli olduğunu göstermektedir (Verbeek, Pulliainen ve Kankaanpää, 2009). Dolayısıyla mesleki kas ve iskelet sistemi rahatsızlığına sebep olabilecek durumların risk düzeylerinin belirlenmesi ve sınıflandırılması büyük önem taşımaktadır. Risk değerlendirmesi olarak adlandırılan bu sürece ilişkin literatürde çeşitli yöntemlerin geliştirildiği görülmektedir (Deste ve Sever, 2019). Bu bölümde literatürde yer alan yöntemlere ilişkin literatür incelemesi yapılacaktır.

\subsection{Literatür İncelemesi}

İşle ilgili mesleki kas ve iskelet sistemi rahatsılıkları, ağrılı kas, tendon ve sinir bozukluğu şeklinde kendisini göstermektedir. Sik tekrarlanan işler ve uygunsuz vücut duruşlarını içeren faaliyetler, çalışırken veya istirahat halinde çalışanlarda ağrılı olabilecek rahatsızlıklara sebep olabilmektedir. İşle ilgili rahatsızlık raporlarına bakıldığında rahatsızlıkların çoğunlukla sırt, üst uzuvlar, omuz ve boyun bölgelerinde yoğunlaştığı görülmektedir. Ergonomik risk değerlendirme/ölçüm yöntemlerinin de bu bölgelere yönelik olarak geliştirilmektedir (Canadian Centre for Occupational Health and Safety, 2014). Literatürde ergonomik risk değerlendirme yöntemleri öznel değerlendirmeler, sistematik gözlemler ve doğrudan gözlemler olmak üzere üç kategori altında ele alınmaktadır (Burdorf ve Van Der Beek, 1999).

Öznel Değerlendirmeler: Çalışanların iş yerlerinde maruz kaldıkları riskleri kendilerinin değerlendirdiği bu kategori, işçi günlükleri, anketler ve kontrol listelerinden oluşmaktadır. Bu yöntemin en önemli avantajı düşük maliyete ve kullanım 
kolaylığına sahip olmasıdır. Bu yöntemde ergonomik analiz yapmak için yeterli bilgi ve tecrübesi olmayan kişiler, kontrol listelerini kullanarak ergonomik açıdan mevcut eksiklikleri tespit edebilmektedirler. Çalışanların maruz kalma algılarında yanılmalar olacağı için kontrol listeleri ve anketler yardımıyla yapılan ergonomik analizlerin geçerliliği ve güvenilirliği tam sağlanamamaktadır (G. C. David, 2005). Fakat analiz sonuçlarına göre daha kapsamlı ergonomik analizlerin hangi alanlarda yapılması gerektiği yönünde öngörü oluşabilmektedir.

Sistematik gözlemler: $\mathrm{Bu}$ kategori kendi arasında basit gözlemsel teknikler ve gelişmiş gözlemsel teknikler olmak üzere ikiye ayrılmaktadır. Basit gözlemsel tekniklerde, bir gözlemci çalışanın pozisyon değişimlerini izleyerek önceden tanımlanmış puan tablosuna kaydetmektedir. Çok çeşitli iş yerlerinde düşük maliyetle kullanılabilen yöntemlerin uygulaması çok zaman almasına rağmen geçerliliği ve güvenilirliği oldukça yüksektir. Yöntemler genellikle statik duruş gerektiren ve tekrarlayan işlerin değerlendirilmesinde kullanılmaktadır. Hali hazırda ergonomik riskleri değerlendirmek için birçok sistematik gözlem yöntemi yer almaktadır. Değerlendirilen maruziyet faktör sayıları yöntemden yönteme değişiklik göstermektedir (David, 2005). Literatürde yer alan başlıca basit gözlemsel yöntemler ile yöntemlerin göstergeleri ve değerlendirdikleri vücut bölümleri aşağıdaki Tablo 2'de verilmiştir.

Tablo 2. Basit Gözlemsel Değerlendirme Araçları (Andreas ve Johanssons, 2018)

\begin{tabular}{|c|c|c|c|c|}
\hline Yöntem ve Kaynak & Vücut bölümü & Yoğunluk & Frekans & Süre \\
\hline ALLA & Alt bölüm & Evet (Duruş) & - & $\sqrt{ }$ \\
\hline ART & Eller/parmaklar & Kısmi (Duruş) & $\sqrt{ }$ & Kismi \\
\hline CTD risk endeksi & Üst ekstremite & Evet (Güç ve duruş) & $\sqrt{ }$ & - \\
\hline HAL & Bilek/eller & Evet (Güç) & $\sqrt{ }$ & - \\
\hline HARM & Boyun/Omuz, Alt kol/bilek & Evet (Güç ve duruş) & $\sqrt{ }$ & $\sqrt{ }$ \\
\hline $\mathrm{KC}$ & El, alt kol & Evet (Güç ve duruş) & Kismi & - \\
\hline KIM I-II, Kaldırma/ Çekme/ İtme & Gövde & Evet (Güç ve duruş) & $\sqrt{ }$ & $\sqrt{ }$ \\
\hline KIM III Elle çalışma & Kol/Bilek & Evet (Güç ve duruş) & $\sqrt{ }$ & $\sqrt{ }$ \\
\hline LUBA & $\begin{array}{l}\text { Boyun, omuzlar, üst sırt, alt sırt, } \\
\text { dirsekler ve bilekler / eller }\end{array}$ & Evet (Duruş) & - & - \\
\hline OCRA & Üst ekstremite & Evet (Güç ve duruş) & $\sqrt{ }$ & - \\
\hline OWAS & Tüm vücut & Evet (Duruş) & $\sqrt{ }$ & - \\
\hline PATH & Tüm vücut & Evet (Güç ve duruş) & $\sqrt{ }$ & - \\
\hline PLIBEL & Tüm vücut & Evet (Güç ve duruş) & $\sqrt{ }$ & - \\
\hline QEC & Sirt, boyun, kol, el & Evet (Duruş) & - & Kismi \\
\hline RAMP & Sirt, üst ekstremite & Evet (Güç ve duruş) & $\sqrt{ }$ & $\sqrt{ }$ \\
\hline REBA & Tüm vücut & Evet (Duruş) & - & - \\
\hline RULA & Tüm vücut & Evet (Duruş) & - & - \\
\hline SI & El, alt kol & Evet (Duruş) & $\sqrt{ }$ & $\sqrt{ }$ \\
\hline WERA & Tüm vücut & Evet (Güç ve duruş) & $\sqrt{ }$ & $\sqrt{ }$ \\
\hline
\end{tabular}

Gelişmiş gözlemsel teknikler daha çok dinamik aktivitelerin yoğun olduğu işlerdeki duruş pozisyonlarını değerlendirebilmek için geliştirilmiştir. $\mathrm{Bu}$ metotta veriler video kayıt cihazı ile toplanmakta ve bilgisayar ortamına aktarılarak 3D Match, ErgoMan, 3DSSPP, Jack. ve Sammie Cad gibi programlar aracılığıyla analiz yapılmaktadır(David, 2005).

Doğrudan gözlemler: Teknoloji alanındaki ilerlemeyle birlikte çalışanların duruşları, hareketleri ve katlandıkları yükler çeşitli teknik yöntemlerle analiz edilmeye başlandı. $\mathrm{Bu}$ kategoride çalışan duruşları, kas aktiviteleri, vücut hareketleri ve güçler hakkında detaylı bilgiler veren ivme ölçer, akıllı giysiler, açı ölçer ve elektromiyografi gibi çeşitli teknik araçlar kullanılarak ergonomik analizler yapılmaktadır. $\mathrm{Bu}$ araçlarla yapılan ergonomik analizlerde, diğer kategorilerdeki yöntemlere kıyasla daha doğru sonuçlar elde edilebilmektedir. Fakat gözlemsel ve öznel değerlendirme yöntemlerinden daha maliyetli ve uzman kişiler tarafindan ele alınabilmektedir (Andreas ve Johanssons, 2018). Yazarlar bu üç kategoriyi geçerlilik ve güvenilirlik bakımından karşılaştırdığında, sistematik gözlemlerin öznel değerlendirmelerin üzerinde olduğunu, doğrudan gözlemlerin de sistematik gözlemlerin üzerinde olduğunu ifade etmişlerdir (Village, Trask, Luong, Chow, Johnson, Koehoorn ve Teschke, 2009).

\subsection{Araştırmada Kullanılan Yöntemler}

$\mathrm{Bu}$ bölümde araştırmada kullanılan yöntemlere ilişkin literatür bilgisi aktarılmıştır.

\subsubsection{Reba}

REBA metodu, Hignett ve McAtamney tarafindan geliştirilmiştir. REBA (Hızlı Tüm Vücut Değerlendirme) yönteminde tüm vücut pratik bir şekilde ergonomik açıdan değerlendirilmektedir. McAtamney ve Hignett, (2000), REBA metodunu özellikle sağlık ve diğer hizmet sektörlerinde bulunan öngörülemeyen çalışma duruşlarını kolaylıkla değerlendirmek için geliştirdiklerini belirtmektedir. Gözlemcinin yönteme ilişkin detaylı bilgisine ihtiyaç duyulmaması ve kolaylıkla uygulanabilmesi, yöntemin avantajlarındandır. Dezavantajı ise farklı işlerde yapılan uygulamalar için ideal gözlem süresinin ve gözlem aralıklarının belirsiz olmasıdır (Ünver Okan ve Kaya, 2015).

Literatür incelendiğinde birçok çalışmada REBA yönteminin kullanıldığı görülmektedir. Sağıroğlu, Coşkun ve Erginel (2015), çalışmalarında, kompresör imalat fabrikasında çalışan işçilerin ergonomik risklerini REBA yöntemi ile değerlendirmiş ve iyileştirme gerçekleştirmişlerdir. Çalışma esnasında birden çok pozisyonu önemli bir zaman, çaba ve maliyet olmadan değerlendirebildiği için REBA yöntemi tercih edilmiştir. 10 farklı iş istasyonunun değerlendirildiği çalışmada, 
krank sepetinin yerinin ve açısının değiştirilmesi, operatörün koltuk yüksekliğinin ayarlanması, fazla yüklerin olduğu istasyonlara taşıma amaçlı vakumlu pergel vinç alınması ve pozisyonlanabilir kaldırma aracının alınması gibi iyileştirme önerilerinde bulunularak ergonomik riskler azaltılmıştır.

Ünver Okan ve Kaya (2015), Trabzon-Of orman fidanlığındaki repikaj işlerinde mevsimlik çalışan 70 kadın işçinin çalışma duruşlarını REBA yöntemi ile analiz ederek risk düzeylerini belirlemişlerdir. Çalışma esnasındaki duruş pozisyonları video kaydına alınmış ve söz konusu kayıtlar ofis ortamında belirli aralıklarla durdurulup REBA yöntemine göre değerlendirilmiştir. Değerlendirme sonucunda replikaj işinin risk puanının 7 olduğunu tespit etmişler ve bu risk puanıyla faaliyetin orta risk grubunda yer aldığını belirtmişlerdir. Sonuç kısmında ise iş yerinin ergonomik bir düzenlemeye ihtiyaç duyduğunu ve çalışanların da çalışma duruşları konusunda bilinçlendirilmesi gerektiğini belirtmişlerdir.

Lasota (2014), mağaza ve internet üzerinden kitap satan bir şirkette, bir siparişin hazırlanma sürecine ilişkin siparişi bulma, ambalajlama ve tasnif etme faaliyetlerini değerlendirmek için REBA yöntemini kullanmıştır. Değerlendirme sonucunda beş duruşun (AC)2, yedi duruşun (AC)3 ve bir duruşun (AC)4 eylem kategorisinde yer aldığını belirlemiştir. Sırtın bükük ve dönük olması, kolların gövdenin üzerinde olması, çalışanın ayakta durması ve paketin ağırlığı riski artıran ana faktörler arasında olduğunu ifade etmiştir. Sipariş hazırlama işindeki çalışanların yüksek düzeyde kas ve iskelet sistemi rahatsızlığı riskine maruz kaldıklarını tespit etmiş ve en kısa zamanda iş istasyonlarının yeniden tasarlanmasının ve çalışma yöntemlerinin tekrar gözden geçirilmesinin gerekli olduğunu vurgulamıştır. Değişikliğin etkinliğini ölçmek için ergonomik düzeltmeler yapıldıktan sonra REBA yöntemiyle aynı faaliyetlerin değerlendirilmesini önermiştir.

Atıcı, Gönen ve Oral (2015), çalışmalarında otomotiv sektörü için kablo imalatı yapan fabrikadaki işçilerin çalışma pozisyonlarını değerlendirmek ve iyileştirmek amacıyla REBA yöntemini kullanmışlardır. Kablo döşeme işlemindeki çalışma duruşları fotoğraflanarak analiz edilmiştir. Analiz sonucunda pozisyonlara ilişkin REBA puanı yüksek çıkmış ve "kısa zaman içerisinde önlem gerektiğgi” ifade edilmiştir. Çalışanlardaki boy farklılıklarının sabit olarak ilerleyen konveyör hattında uygun olmayan duruş pozisyonlarına neden olduğu belirtilmiş ve operatörün boyuna ve çalışma duruşuna göre yükselip alçalabilen montaj masası iyileştirme önerisi olarak sunulmuştur.

Savitri, Mulyati ve Aziz (2012), bahçe işinde çalışan yedi işçinin yaptığı işleri 23 parçaya ayırarak işçilerin çalışma pozisyonlarını değerlendirmişlerdir. İşle ilgili ağrı semptomlarının varlığını araştırmak, uygunsuz çalışma duruşlarıyla ilgili riskleri belirlemek ve çalışma yöntemlerini iyileştirilmek amacıyla bu çalışmayı gerçekleştirmiş̧lerdir.
Çalışmada, işle ilgili ağrı oluşumunu tespit etmek için Nordic Kas-İskelet Sistemi Anketi kullanılırken; çalışma duruşlarına ilişkin risk değerlendirmesi Hızlı Tüm Vücut Değerlendirmesi (REBA) yöntemi ile yapılmıştır. Sonuçlar, tüm işçilerin, işin öncesinde ve sonrasında ağrı semptomları yaşadığını göstermiştir. REBA analizine göre işlerin \%82,6'sının orta, \%10,9'unun yüksek, \%4,3'ünün çok yüksek ve \%2,2'sinin düşük seviye risk grubunda olduğu tespit edilmiştir. Çalışmanın sonuç kısmında ise riskli olan çalışma duruşlarına ilişkin iyileştirme önerileri geliştirilmiştir.

REBA yönteminin uygulanması beş adımda gerçekleşmektedir (Koç ve Testik, 2016):

- $\quad$ İşin gözlemlenmesi

- Değerlendirilecek pozisyonların seçilmesi

- Pozisyonların puanlanması

- REBA puanının hesaplanması

- Eylem seviyesinin ve risk düzeyinin belirlenmesi

\section{Adım: İşin Gözlemlenmesi}

İşyeri düzeni, ekipman kullanımı ve çalışanın risk alma konusundaki davranışı da dahil olmak üzere yapılan iş gözlemlenir. Eğer mümkünse kamera veya fotoğraf makinesi ile veriler kaydedilir. Kayıt esnasında ortaya çıkabilecek eksiklikleri ve açı kayıplarını minimize etmek için birden fazla görüntünün alınması önerilmektedir.

\section{Adım: Değerlendirilecek Pozisyonun Seçilmesi}

Birinci adımdaki gözlemden sonra hangi pozisyonun değerlendirileceğine karar verilir. Pozisyon seçiminde aşağıdaki kriterlerden bir veya birkaçı dikkate alınabilir;

- $\quad$ En sik tekrar eden duruş

- $\quad$ En uzun süren duruş

- Aşırı kuvvet veya kas kullanımını gerektiren duruş

- Özellikle kuvvet uygulama esnasında ortaya çıkan dengesiz veya uygunsuz duruş

- Önlem, bilgilendirme veya diğer değişikliklerle iyileştirilmesi muhtemel duruş

\section{Adım: Pozisyonların Puanlanması}

REBA yöntemi vücudu A ve B şeklinde iki gruba ayırmaktadır. A grubunda, boyun, gövde ve bacaklar yer alırken; B grubunda, üst kol, alt kol ve el bilekler yer almaktadır. Şekil 1'de A, Şekil 2'de B grubu için puanlama kriterleri yer almaktadır. Şekillerden de anlaşılacağ duruş esnasında oluşturduğu açılara göre puanlar verilmektedir. Puanlar duruma bağlı olarak artırılıp azaltılabilmektedir. Örneğin B grubundaki üst kol, açısına göre puanlandiktan sonra pozisyonda omuzda yükselme de varsa hesaplanan puana 1 puan eklenir. 


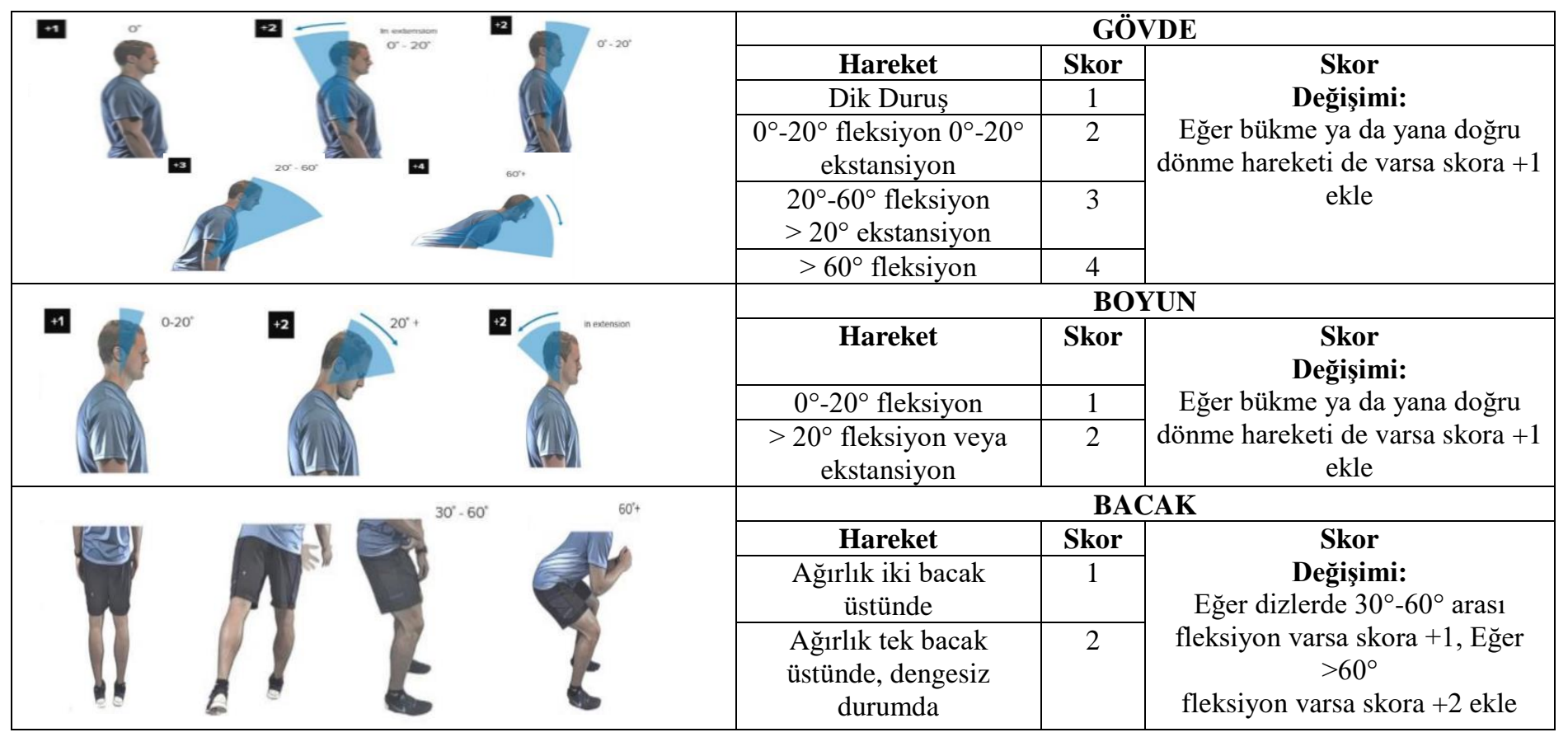

Şekil 1. Reba Yöntemi Grup A Puanlaması (Koç ve Testik, 2016)

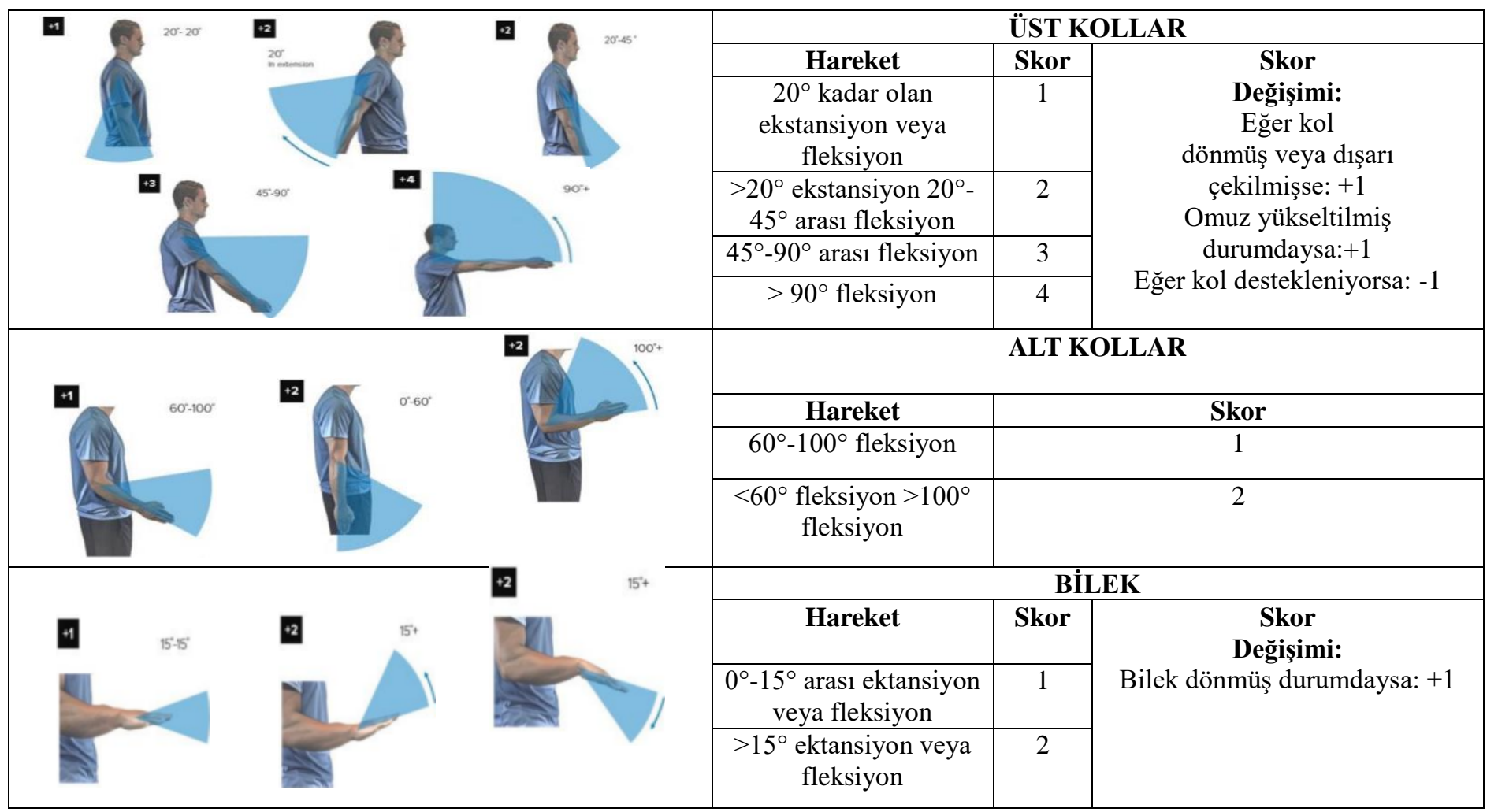

Şekil 2. Reba Yöntemi Grup B Puanlaması (Koç ve Testik, 2016)

\section{Adım: REBA Puanının Hesaplanması}

Şekil 1 ve Şekil 2'de yer alan vücut bölümleri için ayrı ayrı puanlamalar yapıldıktan sonra puanları tek bir puana dönüştürmek için öncelikle Tablo 6'daki puanlama cetveli kullanılır. Tablo 6'da belirlenen puanlar, Şekil 3'deki diyagramın üst tarafındaki boş kutucukların soluna ve sağına kaydedilir. Gövde, boyun ve bacak için kaydedilen puana, Tablo 3'deki yük/kuvvet puanı eklenerek A puanı; üst kol alt kol ve bilek için kaydedilen puana Tablo 4'deki kavrama puanı eklenerek B puanı elde edilir. A ve B puanları Tablo 7'deki puanlama matrisinde birleştirilerek $\mathrm{C}$ puanı elde edilir. Son olarak C puanına, varsa Tablo 5'deki hareket puanı eklenerek REBA puanı elde edilir.

\section{Adım: Eylem Seviyesinin Belirlenmesi}

REBA puanı hesaplandıktan sonra Tablo 8'de yer alan Eylem Seviyeleri kullanılarak puanın risk seviyesi ve risk puanına göre uygulanması gereken eylem belirlenir. 
Tablo 3. Reba Yöntemi Yük/Kuvvet Puanlaması (Koçve Testik, 2016)

\begin{tabular}{|c|c|c|c|}
\hline $\mathbf{0}$ & $\mathbf{1}$ & $\mathbf{2}$ & $\mathbf{+ 1}$ \\
\hline$<5 \mathrm{~kg}$ & $5-10 \mathrm{~kg}$ & $>10 \mathrm{~kg}$ & Ani veya hızla artan güç kullanımı gerektiğinde \\
\hline
\end{tabular}

Tablo 4. Reba Yöntemi Yük Kavrama Puanlaması (Koç ve Testik, 2016)

\begin{tabular}{|c|c|c|c|}
\hline 0 (İyi) & $\mathbf{1}$ (Orta) & 2 (Zayıf) & 3 (Kabul Edilemez) \\
\hline $\begin{array}{c}\text { Elle iyi kavrama ve orta vade } \\
\text { güçlü kavrama }\end{array}$ & $\begin{array}{c}\text { Elle kavrama kabul edilebilir; } \\
\text { ancak ideal değil ya da } \\
\text { kavrama, vücudun başka bir } \\
\text { bölümüyle kabul edilebilir }\end{array}$ & $\begin{array}{c}\text { Mümkün olmasına } \\
\text { rağmen elle kavrama } \\
\text { kabul edilemez }\end{array}$ & $\begin{array}{c}\text { Elle kavrama uygunsuz ve } \\
\text { güvensiz; tutacak yok ya da } \\
\text { kavrama, vücudun diğer } \\
\text { bölümlerinin kullanılmasıly kabul } \\
\text { edilemez }\end{array}$ \\
\hline
\end{tabular}

Tablo 5. Reba Yöntemi Hareket Puanlaması (Koç ve Testik, 2016)

\begin{tabular}{|c|c|}
\hline Skor & Tanım \\
\hline $\mathbf{+ 1}$ & Bir ya da daha fazla vücut bölümü statikse, örneğin 1 dakikadan daha uzun süre tutma \\
\hline $\mathbf{+ 1}$ & Tekrarlanan kısa aralıklı eylemler varsa, örneğin dakikada 4 kereden fazla tekrarlama (yürüme hariç) \\
\hline $\mathbf{+ 1}$ & Eylem, duruşta hızlı büyük değişikliklere neden oluyorsa ya da dengesiz duruş \\
\hline
\end{tabular}

Tablo 6. Reba Yöntemi Grup A-B Vücut Bölümleri Puanlaması (Koç ve Testik, 2016)

\begin{tabular}{|c|c|c|c|c|c|c|c|c|c|c|c|c|c|c|c|c|c|c|c|c|c|}
\hline \multirow{4}{*}{\multicolumn{2}{|c|}{ Tablo A }} & \multicolumn{12}{|c|}{ BOYUN } & \multirow{4}{*}{\multicolumn{2}{|c|}{ Tablo B }} & \multicolumn{6}{|c|}{ ALT KOL } \\
\hline & & & \multicolumn{3}{|c|}{1} & \multicolumn{4}{|c|}{2} & \multicolumn{4}{|c|}{3} & & & \multicolumn{3}{|c|}{1} & \multicolumn{3}{|c|}{2} \\
\hline & & \multicolumn{4}{|c|}{ BACAKLAR } & \multicolumn{4}{|c|}{ BACAKLAR } & \multicolumn{4}{|c|}{ BACAKLAR } & & & \multicolumn{3}{|c|}{ BILLEK } & \multicolumn{3}{|c|}{ BİLEK } \\
\hline & & 1 & 2 & 3 & 4 & 1 & 2 & 3 & 4 & 1 & 2 & 3 & 4 & & & 1 & 2 & 3 & 1 & 2 & 3 \\
\hline \multirow{5}{*}{ ○ } & 1 & 1 & 2 & 3 & 4 & 1 & 2 & 3 & 4 & 3 & 4 & 5 & 6 & \multirow{6}{*}{$\begin{array}{l}\overline{0} \\
\underline{1} \\
\dot{n} \\
: D\end{array}$} & 1 & 1 & 2 & 2 & 1 & 2 & 3 \\
\hline & 2 & 2 & 3 & 4 & 5 & 3 & 4 & 5 & 6 & 4 & 5 & 6 & 7 & & 2 & 1 & 2 & 3 & 2 & 3 & 4 \\
\hline & 3 & 2 & 4 & 5 & 6 & 4 & 5 & 6 & 7 & 5 & 6 & 7 & 8 & & 3 & 3 & 4 & 5 & 4 & 5 & 5 \\
\hline & 4 & 3 & 5 & 6 & 7 & 5 & 6 & 7 & 8 & 6 & 7 & 8 & 9 & & 4 & 4 & 5 & 5 & 5 & 6 & 7 \\
\hline & 5 & 4 & 5 & 6 & 7 & 6 & 7 & 8 & 9 & 7 & 8 & 9 & 9 & & 5 & 6 & 7 & 8 & 7 & 8 & 8 \\
\hline & & & & & & & & & & & & & & & 6 & 7 & 8 & 8 & 8 & 9 & 9 \\
\hline
\end{tabular}

Tablo 7. Reba Yöntemi Genel Puanlama (Sevimli, Atıcı Ulusu ve Gündüz, 2018)

\begin{tabular}{|c|c|c|c|c|c|c|c|c|c|c|c|c|c|}
\hline \multirow{2}{*}{\multicolumn{2}{|c|}{ Tablo C }} & \multicolumn{12}{|c|}{ GRUP B PUANI } \\
\hline & & 1 & 2 & 3 & 4 & 5 & 6 & 7 & 8 & 9 & 10 & 11 & 12 \\
\hline \multirow{12}{*}{ 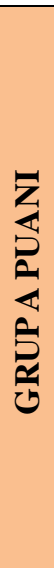 } & 1 & 1 & 1 & 1 & 2 & 3 & 3 & 4 & 5 & 6 & 7 & 7 & 7 \\
\hline & 2 & 2 & 2 & 2 & 3 & 4 & 4 & 5 & 6 & 6 & 7 & 7 & 8 \\
\hline & 3 & 3 & 3 & 3 & 3 & 4 & 5 & 6 & 7 & 7 & 8 & 8 & 8 \\
\hline & 4 & 4 & 4 & 4 & 4 & 5 & 6 & 7 & 8 & 8 & 9 & 9 & 9 \\
\hline & 5 & 5 & 4 & 4 & 5 & 6 & 7 & 8 & 8 & 9 & 9 & 9 & 9 \\
\hline & 6 & 6 & 6 & 6 & 7 & 8 & 8 & 9 & 9 & 10 & 10 & 10 & 10 \\
\hline & 7 & 7 & 7 & 7 & 8 & 9 & 9 & 9 & 10 & 10 & 11 & 11 & 11 \\
\hline & 8 & 8 & 8 & 8 & 9 & 10 & 10 & 10 & 10 & 10 & 11 & 11 & 11 \\
\hline & 9 & 9 & 9 & 9 & 10 & 10 & 10 & 11 & 11 & 11 & 12 & 12 & 12 \\
\hline & 10 & 10 & 10 & 10 & 11 & 11 & 11 & 11 & 12 & 12 & 12 & 12 & 12 \\
\hline & 11 & 11 & 11 & 11 & 11 & 12 & 12 & 12 & 12 & 12 & 12 & 12 & 12 \\
\hline & 12 & 12 & 12 & 12 & 12 & 12 & 12 & 12 & 12 & 12 & 12 & 12 & 12 \\
\hline
\end{tabular}




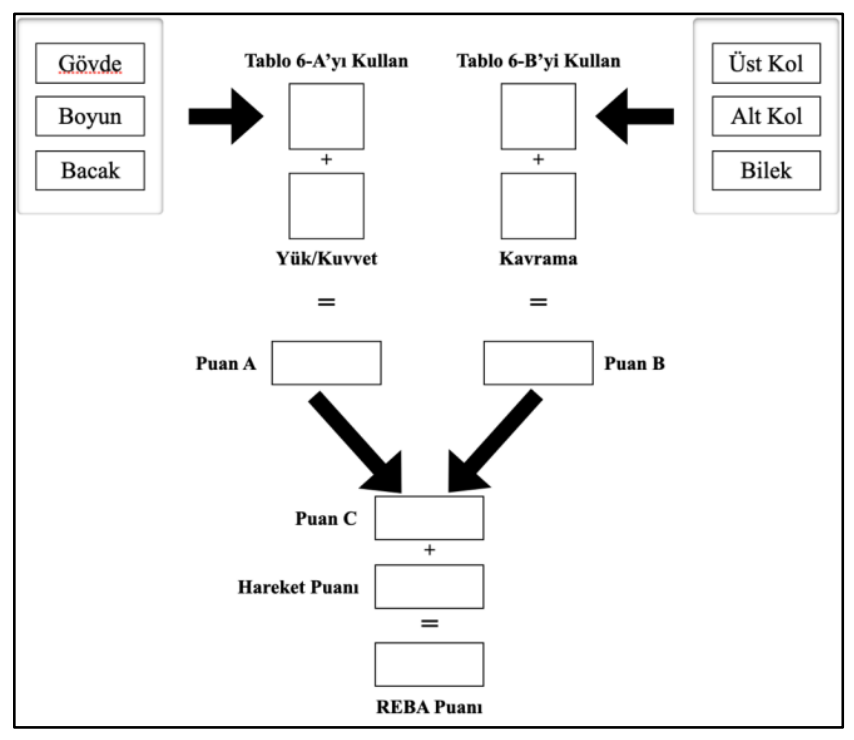

Şekil 1. Reba Yöntemi Puanlama Diyagramı (Koç ve Testik, 2016)

Tablo Hata! Belgede belirtilen stilde metne rastlanmadı..1. Reba Yöntemi Eylem Seviyeleri (Koç ve Testik, 2016)

\begin{tabular}{|c|c|c|c|}
\hline REBA Puanı & Risk Seviyesi & Eylem Seviyesi & Önlem \\
\hline 1 & İhmal Edilebilir & 0 & Gerekli Değil \\
\hline $2-3$ & Düşük & 1 & Gerekli Olabilir \\
\hline $4-7$ & Orta & 2 & Gerekli \\
\hline $8-10$ & Yüksek & 3 & Kısa Süre İçerisinde Gerekli \\
\hline $11-15$ & Çok Yüksek & 4 & Acilen Gerekli \\
\hline
\end{tabular}

\subsubsection{Rula}

Nottingham Üniversitesinden McAtamney ve Corlett tarafindan tasarlanmış ve 2 Nisan $1993^{\circ}$ te Applied Ergonomics dergisinin 24. cildinin 2. sayısında yayımlanmıştır (McAtamney ve Corlett, 1993). RULA (Hızlı Üst Uzuv Değerlendirmesi), işçilerin maruziyetlerine bağlı olarak üst uzuvlarında bozukluk oluşturacak risk faktörlerini araştırmak için geliştirilmiş̧ir. Metot, kolay kullanım için tasarlandığından kullanıcılarının ileri düzeyde ergonomi bilgisine sahip olması gerekmemektedir (Middlesworth, 2019).

Çalışma duruşlarının incelenmesi için tasarlanmış olan RULA, farklı ülkelerde çeşitli sektörlerde yapılan çalışmalarda yaygın olarak kullanılmaktadır. Bu çalışmalardan birisinde Rahman, (2014) Bangladeş'in önde gelen seramik endüstrisinde faaliyet göstermekte olan fabrikadaki işçilerin çalışma duruşlarını RULA aracılığıyla değerlendirmiştir. Çalışmada amaç, çalışanların farklı vücut bölgeleriyle ilişkili risk düzeyinin belirlenmesi ve iyi veya kötü çalışan duruşlarının tespit edilmesi şeklinde açıklanmıştır. Bu amaç doğrultusunda yapılan çalışma sonucunda, birçok işçinin üst ektremite rahatsızlığına maruz kaldığ 1 tespit edilmiştir. RULA analizi ile üretim bölümünde çalışan işçiler için risksiz herhangi bir duruşun olmadığı ortaya çıkmıştır. Analizlerin nihai sonucunda, iş̧ilerin \%15,38'i için duruş pozisyonları daha fazla araştırılmalı, işçilerin \%41,02'si için duruş pozisyonları incelenmeli ve kısa süre içerisinde değiştirilmeli ve işçilerin $\% 43,59$ 'u için duruş pozisyonları acilen değiştirilmeli, şeklinde ifade edilmiştir.

Massaccesi vd., (2003) yaptıkları bir çalışmada profesyonel sürücülerin duruş pozisyonlarını RULA yöntemi ile analiz etmişlerdir. Çöp toplama ve yol yıkama araçlarını kullanan 77 şoför, incelemeye alınmıştır. Çalışmada denekler tarafından ifade edilen vücut ağrıları ile vücut bölümlerine ilişkin tespit edilen puanlar arasında anlamlı bir ilişkinin olduğu bildirilmiştir. Özellikle boyun bölgesi puanı yüksek çıkmış ve boynun yoğun yük altında olduğu tespit edilmiştir. Ayrıca ayarlanabilir koltuk kullanan sürücüler ile kullanmayan sürücülerin RULA puanları arasında farklı sonuçlar tespit edilmiştir. Kamyonlarda ayarlanabilir koltuk kullanımının rahatsızlıkları azaltabileceği sonucuna ulaşılmıştır. $\mathrm{Bu}$ çalışmayla RULA yönteminin sürücülerin duruş pozisyonlarını değerlendirmede hızlı ve uygun bir risk değerlendirme aracı olduğu kanıtlanmıştır.

Sencer, Eldem, Top ve Şahin, (2019) yaptıkları çalışma kapsamında, zemin yüksekliği yer yer farklı olan ve teknik açıdan maksimum sayıda açılır-kapanır havalandırma penceresi bulunan otobüsteki yolcuların, koltuğa oturarak pencereyi tamamen açması halinde ortaya çıkabilecek duruş pozisyonlarının ergonomik analizinde CATIA V5 R21 programının RULA aracını kullanmışlardır. Otobüsün sol ve sağ pencerelerinin altında bulunan bütün koltuklar ayrı ayrı değerlendirmeye alınmıştır. Çalışma sonuç kısmında, zemin yüksekliği farklı olan koltuklar için farklı ergonomik risk değerlerinin olduğu tespit edilmiştir. 1, 2, 5, ve 6 nolu koltukların risk puanlarının, 3,4 ve 7 nolu koltukların risk puanlarına göre daha düşük olduğu tespit edilmiştir. Risk puanı 4 olarak hesaplanan 3,4 ve 7 nolu koltuklar için acil bir değişikliğe ihtiyaç olmadığı açıklanmıştır.

Neşeli, (2016) tez çalışmasında çeşitli sektörlerde faaliyet gösteren kalıp imalat fabrikası çalışanları için ergonomik analiz yapmıştır. Çalışmada öncelikle her bir iş için iş tanımlaması yapılmıştır. Sonrasında ise bu işlerin yapımı esnasındaki duruşlar RULA ve REBA yöntemleri ile analiz edilmiştir. Çalışmanın sonuç kısmında risk analizinde hesaplanan puanlar değerlendirilmiş ve risk puanına göre iyileştirme önerilerinde bulunulmuştur. 
RULA yönteminin uygulanması 3 adımdan oluşmaktadır (Neşeli, 2016):

- Değerlendirilecek duruşun belirlenmesi,

- Duruşların puanlanması,

- Eylem seviyesinin belirlenmesi,

\section{Adım: Değerlendirilecek duruşun belirlenmesi}

RULA değerlendirmesi, çalışma döngüsünde bir anı temsil etmektedir. Bu sebeple değerlendirilecek duruşlar seçilmeden önce, çalışma döngüsü içerisindeki bütün duruşların dikkatli bir şekilde gözlemlenmesi gerekmektedir. Sonrasında ise bu duruşlardan en sık tekrar eden, en uzun süren veya çalışanı en çok zorlayan duruşlar değerlendirilmek üzere seçilmektedir.

\section{Adım: Duruşların Puanlanması}

RULA yöntemi de tıpkı REBA yöntemi gibi vücudu A ve B şeklinde iki gruba ayırmaktadır. A grubunda, üst kol, alt kol ve el bilekler yer alırken; B grubunda, boyun, gövde ve bacaklar yer almaktadır. Şekil 2.4.'de A, Şekil 2.5.'de B grubu için puanlama kriterleri yer almaktadır.

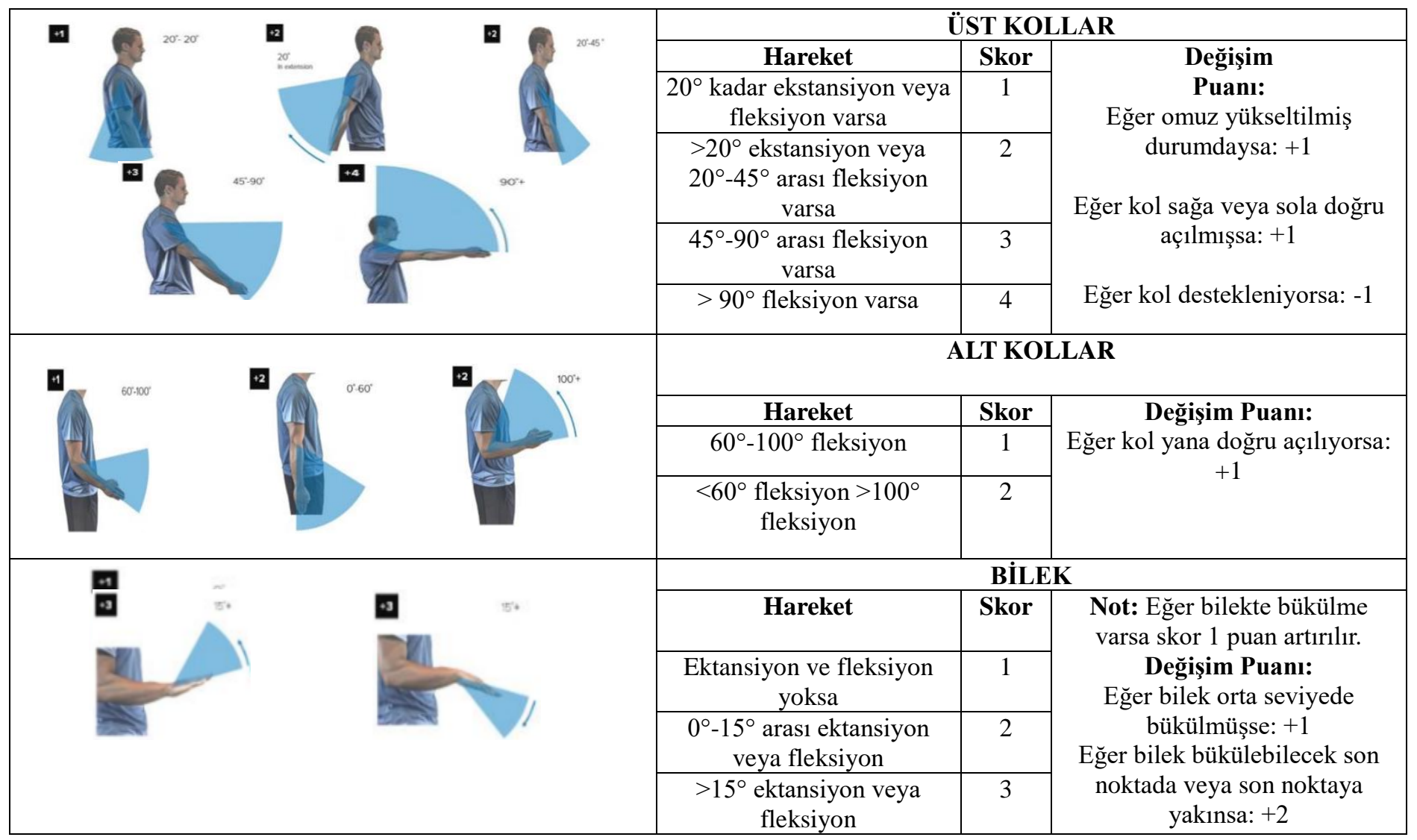

Şekil 4. Rula Yöntemi Grup A Puanlaması (Middlesworth, 2019)

Şekillerde belirtilen kriterlere göre duruşlara puanlar verilmektedir. Puanlar duruma bağlı olarak artırılıp azaltılabilmektedir. Örneğin A grubundaki üst kol, açısına göre puanlandiktan sonra duruşta kol destekleniyorsa hesaplanan puandan 1 puan çıkarılır. Vücut bölümleri için puanlar belirlendikten sonra puanları tek bir puana dönüştürmek için öncelikle Tablo 9 ve Tablo 10'daki puanlama cetvelleri kullanılır ve puanlar Şekil 6'daki diyagrama kaydedilir. İki grup için kaydedilen puana, Tablo 12'de yer alan yük/kuvvet kas kullanım puanları ayrı ayrı eklenerek A puanı ve B puanı elde edilir. A ve B puanları Tablo 11'deki puanlama matrisinde birleştirilerek C puanı elde edilir. Elde edilen $\mathrm{C}$ puanı aynı zamanda RULA puanını da ifade etmektedir. 
European Journal of Science and Technology

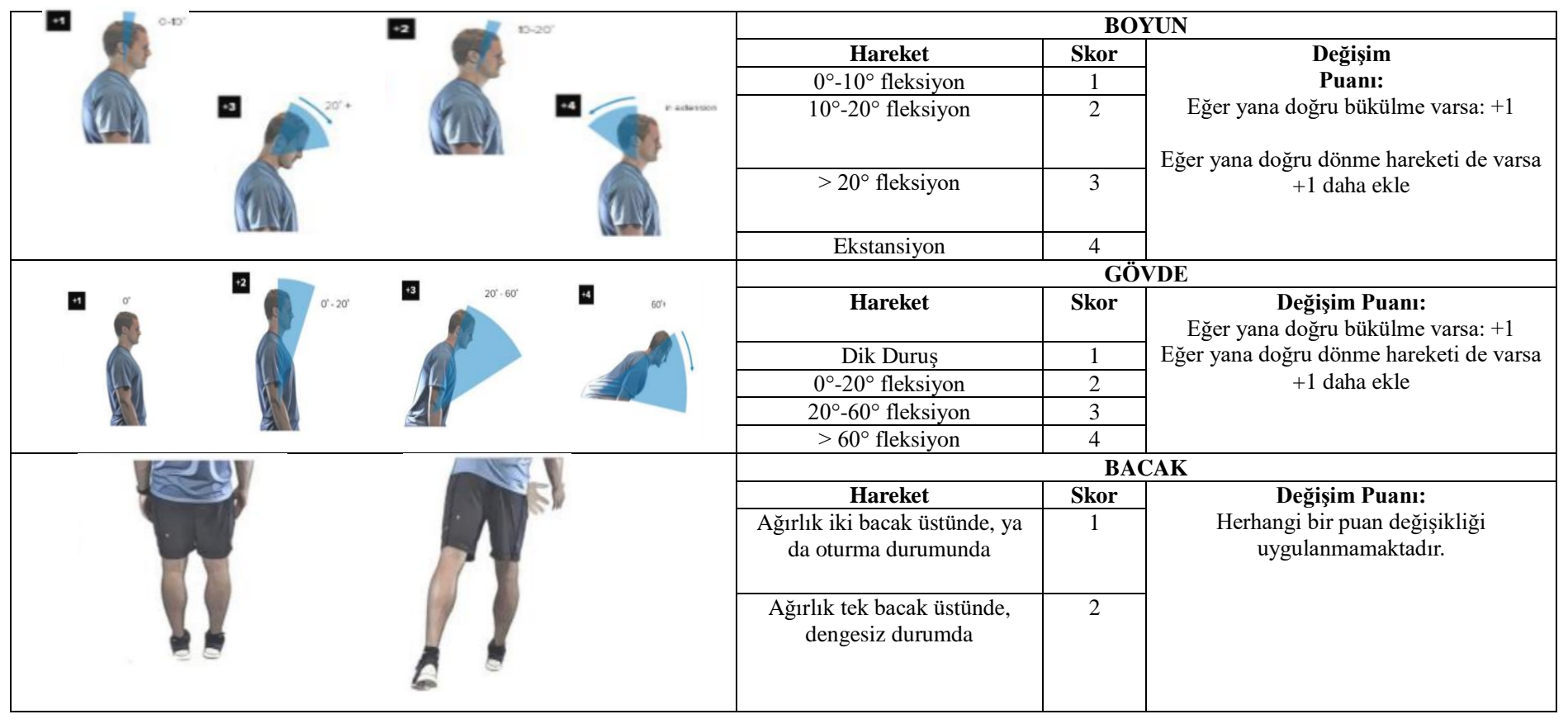

Şekil 2. Rula Yöntemi Grup B Puanlaması (Middlesworth, 2019)

Tablo 9. Rula Yöntemi Grup A Vücut Bölümleri Puanlaması (Middlesworth, 2019)

\begin{tabular}{|c|c|c|c|c|c|c|c|c|c|}
\hline \multirow{2}{*}{\multicolumn{2}{|c|}{ Tablo A }} & \multicolumn{8}{|c|}{ Bilek } \\
\hline & & \multicolumn{2}{|c|}{1} & \multicolumn{2}{|c|}{2} & \multicolumn{2}{|c|}{3} & \multicolumn{2}{|c|}{4} \\
\hline \multirow[t]{2}{*}{ Üst Kol } & \multirow[t]{2}{*}{ Alt Kol } & \multicolumn{8}{|c|}{ Bilek Bükülmesi } \\
\hline & & 1 & 2 & 1 & 2 & 1 & 2 & 1 & 2 \\
\hline \multirow[t]{3}{*}{1} & 1 & 1 & 2 & 2 & 2 & 2 & 3 & 3 & 3 \\
\hline & 2 & 2 & 2 & 2 & 2 & 3 & 3 & 3 & 3 \\
\hline & 3 & 2 & 3 & 3 & 3 & 3 & 3 & 4 & 4 \\
\hline \multirow[t]{3}{*}{2} & 1 & 2 & 3 & 3 & 3 & 3 & 4 & 4 & 4 \\
\hline & 2 & 3 & 3 & 3 & 3 & 3 & 4 & 4 & 4 \\
\hline & 3 & 3 & 4 & 4 & 4 & 4 & 4 & 5 & 5 \\
\hline \multirow[t]{3}{*}{3} & 1 & 3 & 3 & 4 & 4 & 4 & 4 & 5 & 5 \\
\hline & 2 & 3 & 4 & 4 & 4 & 4 & 4 & 5 & 5 \\
\hline & 3 & 4 & 4 & 4 & 4 & 4 & 5 & 5 & 5 \\
\hline \multirow[t]{3}{*}{4} & 1 & 4 & 4 & 4 & 4 & 4 & 5 & 5 & 5 \\
\hline & 2 & 4 & 4 & 4 & 4 & 4 & 5 & 5 & 5 \\
\hline & 3 & 4 & 4 & 4 & 5 & 5 & 5 & 6 & 6 \\
\hline \multirow[t]{3}{*}{5} & 1 & 5 & 5 & 5 & 5 & 5 & 6 & 6 & 7 \\
\hline & 2 & 5 & 6 & 6 & 6 & 6 & 7 & 7 & 7 \\
\hline & 3 & 6 & 6 & 6 & 7 & 7 & 7 & 7 & 8 \\
\hline \multirow[t]{3}{*}{6} & 1 & 7 & 7 & 7 & 7 & 7 & 8 & 8 & 9 \\
\hline & 2 & 8 & 8 & 8 & 8 & 8 & 9 & 9 & 9 \\
\hline & 3 & 9 & 9 & 9 & 9 & 9 & 9 & 9 & 9 \\
\hline
\end{tabular}

Tablo10. Rula Yöntemi Grup B Vücut Bölümleri Puanlaması (Middlesworth, 2019)

\begin{tabular}{|c|c|c|c|c|c|c|c|c|c|c|c|c|}
\hline \multirow{2}{*}{ Tablo B } & \multicolumn{12}{|c|}{ Gövde } \\
\hline & & & & & & & & & & & & \\
\hline \multirow{2}{*}{ Boyun } & \multicolumn{12}{|c|}{ Bacak } \\
\hline & 1 & 2 & 1 & 2 & 1 & 2 & 1 & 2 & 1 & 2 & 1 & 2 \\
\hline 1 & 1 & 3 & 2 & 3 & 3 & 4 & 5 & 5 & 6 & 6 & 7 & 7 \\
\hline 2 & 2 & 3 & 2 & 3 & 4 & 5 & 5 & 5 & 6 & 7 & 7 & 7 \\
\hline 3 & 3 & 3 & 3 & 4 & 4 & 5 & 5 & 6 & 6 & 7 & 7 & 7 \\
\hline 4 & 5 & 5 & 5 & 6 & 6 & 7 & 7 & 7 & 7 & 7 & 8 & 8 \\
\hline 5 & 7 & 7 & 7 & 7 & 7 & 8 & 8 & 8 & 8 & 8 & 8 & 8 \\
\hline 6 & 8 & 8 & 8 & 8 & 8 & 8 & 8 & 9 & 9 & 9 & 9 & 9 \\
\hline
\end{tabular}

Tablo 11. Rula Yöntemi Genel Puanlama (Middlesworth, 2019)

\begin{tabular}{|c|c|c|c|c|c|c|c|c|}
\hline \multirow{2}{*}{\multicolumn{2}{|c|}{ Tablo C }} & \multicolumn{7}{|c|}{ Boyun, Gövde, Bacak } \\
\hline & & 1 & 2 & 3 & 4 & 5 & 6 & $7+$ \\
\hline \multirow{8}{*}{ 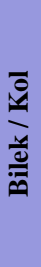 } & 1 & 1 & 2 & 3 & 3 & 4 & 5 & 5 \\
\hline & 2 & 2 & 2 & 3 & 4 & 4 & 5 & 5 \\
\hline & 3 & 3 & 3 & 3 & 4 & 4 & 5 & 6 \\
\hline & 4 & 3 & 3 & 3 & 4 & 5 & 6 & 6 \\
\hline & 5 & 4 & 4 & 4 & 5 & 6 & 7 & 7 \\
\hline & 6 & 4 & 4 & 5 & 6 & 6 & 7 & 7 \\
\hline & 7 & 5 & 5 & 6 & 6 & 7 & 7 & 7 \\
\hline & $8+$ & 5 & 5 & 6 & 7 & 7 & 7 & 7 \\
\hline
\end{tabular}


Tablo 12. Rula Yöntemi İlave Puanlama (Middlesworth, 2019)

\begin{tabular}{|c|c|c|c|}
\hline \multicolumn{2}{|r|}{ Yük/Kuvvet Puanlaması } & \multicolumn{2}{|r|}{ Kas Kullanım Puanlaması } \\
\hline Skor & Tanım & Skor & Tanım \\
\hline $\mathbf{0}$ & Yük <2 kg (ara ara) & \multirow[t]{4}{*}{1} & \multirow{4}{*}{$\begin{array}{l}1 \text { dakikadan fazla bir süre statik olma veya dakikada } \\
4 \text { 'den fazla tekrar etme }\end{array}$} \\
\hline 1 & $2 \mathrm{~kg} \leq$ Yük $<10 \mathrm{~kg}$ (ara ara) & & \\
\hline 2 & $2 \mathrm{~kg} \leq$ Yük $<10 \mathrm{~kg}$ (Statik ve tekrarl1) & & \\
\hline 3 & Yük $\geq 10 \mathrm{~kg}$ veya kuvvette hızlı artış & & \\
\hline
\end{tabular}

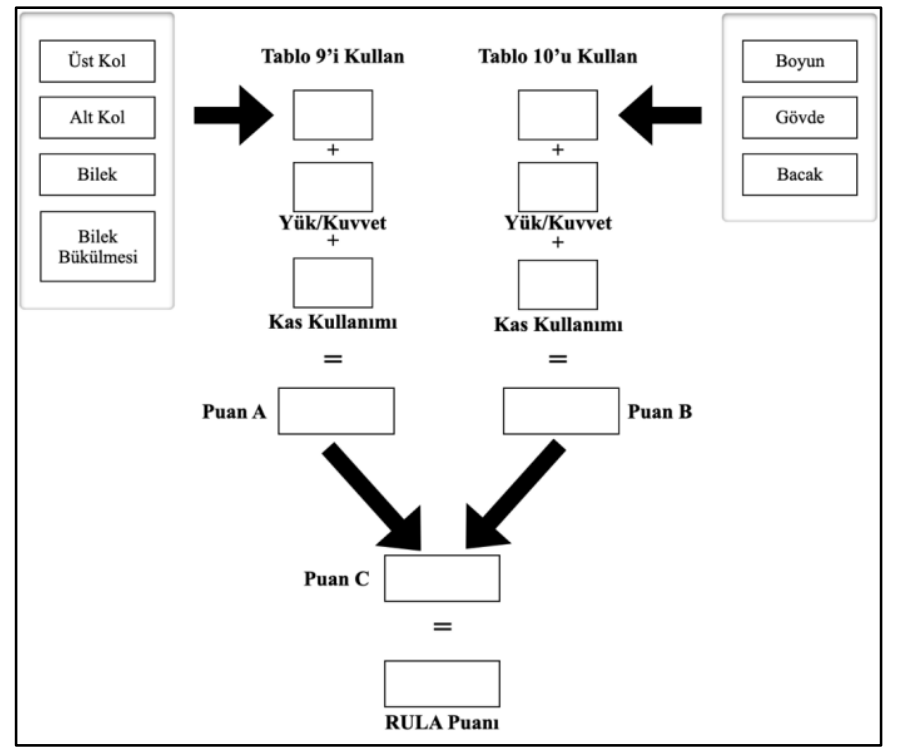

Şekil 3. Rula Yöntemi Puanlama Diyagramı (Middlesworth, 2019)

Tablo 13. Rula Yöntemi Eylem Seviyeleri (Rahma ve Faiz, 2019)

\begin{tabular}{|c|c|c|c|}
\hline RULA Puanı & Risk Seviyesi & Eylem Seviyesi & Önlem \\
\hline $1-2$ & İhmal Edilebilir & 0 & Gerekli Değil \\
\hline $3-4$ & Orta & 1 & Gerekli Olabilir \\
\hline $5-6$ & Yüksek & 2 & Kısa Süre İçerisinde Gerekli \\
\hline 7 & Çok Yüksek & 3 & Acilen Gerekli \\
\hline
\end{tabular}

\section{Adım: Eylem Seviyesinin Belirlenmesi}

RULA puanı hesaplandıktan sonra Tablo 13'de yer alan Eylem Seviyeleri kullanılarak puanın risk seviyesi ve risk puanına göre uygulanması gereken eylem belirlenir.

\subsubsection{Qec}

QEC (Hızlı Maruziyet Değerlendirme) metodu ilk 1998 yılında Lee ve Buckle tarafından geliştirilmiştir. Yöntem belirli bir süre kullanıldıktan sonra, 2005 y1lında David, Woods ve Buckle, 206 uygulayıcıdan aldıkları geri bildirimlere göre içeriği tekrar gözden geçirerek yönteme son şeklini vermiştir (G. David, Woods, Li ve Buckle, 2008). QEC' in Türkçe versiyonu ise 2008 yılında oluşturmuştur. Türkçe versiyonu, İstanbul Üniversitesi Tıp Fakültesi Hastanesi'nde çalışan 20 temizlik görevlisi üzerinde uygulanarak güvenilirliği tekrardan incelemeye alınmıştır. İnceleme neticesinde yöntemin güvenilir olduğu açıklanmıştır (Özcan, Kesiktas, Alptekin ve Özcan, 2008).

QEC yöntemi, öğrenim basitliği, kullanım kolaylığı, değişiklikleri önceliklendirmesi gibi çeşitli avantajları bünyesinde barındırmaktadır. Yöntem, çalışanın en çok hangi işlerde zorlandığının anlaşılmasına, zorlanmaların temel nedenlerinin tespit edilmesine katkı sunmaktadır. Yöntemde hem genel vücut risk puanı hem de vücut bölümleri için alt puanlar belirlenmektedir. $\mathrm{Bu}$ alt puanlara göre vücut bölümlerinin risk seviyeleri tespit edilebilmektedir (İnalçuk, 2019). Bunlara ek olarak yöntemde hem çalışandan hem de gözlemciden girdi alınarak çift taraflı bir değerlendirme yapılmaktadır (Alici, Ulusu Atıcı ve Gündüz, 2017).

QEC yöntemi yayımlandığı günden bu yana farklı sektörlerde çeşitli çalışmalarda kullanılmıştır. Ericsson, Björklund ve Wahlström, (2012) bir hastanedeki farklı meslek gruplarıyla yaptıkları pilot çalışmada, QEC yönteminin uygulanabilirliğini test etmeye çalışmışlardır. 23 çalışanın gözlemlendiği çalışmada, QEC yöntemini test etmek amacıyla, en yaygın yapılan işle, en yorucu kabul edilen iş arasındaki maruziyet seviyeleri karşılaştırılmıştır. Çalışmanın sonucunda QEC yönteminin, boyunda, üst ekstremitelerde ve beldeki fiziksel risk faktörlerini kapsayan hızlı, mantıklı ve pratik bir risk değerlendirme aracı olma beklentilerini karşıladığı ortaya konmuştur. 
Rahmani, Shahnavazi, Fazli ve Ghasemi, (2020) çimento fabrikasındaki çalışanların kas ve iskelet sistemi rahatsızlık düzeylerini belirlemek için QEC yöntemini kullanarak çalışma gerçekleştirmişlerdir. Çalışmaya 150 kişinin katılımı sağlanmıştır. Araştırma sonucunda organlarda oluşan kas ve iskelet sistemi rahatsızlıklarını tespit etmede QEC yönteminin iyi bir belirleyici olduğunu ifade etmişlerdir.

Bulduk, Bulduk, Süren ve Ovalı, (2014) Ankara'da günde yaklaşık 10-12 saat çalışan taksi şoförlerine, yaşadıkları KİSR'nin nedenlerini belirlemek için QEC yöntemi uygulamışlardır. Çalışmaya 382 taksi sürücüsü katılmıştır. Yapılan araştırma sonucunda, taksi şoförlerinde risklerin yüksek olduğu görülmüştür. Dengesiz duruşlar, tekrarlanan hareketler, titreşim, yola sürekli dikkat ve işle ilgili stres KİSR'e neden olan ana risk faktörleri olarak belirlenmiştir.

İnalçuk, (2019) Metal Endüstrisinde faaliyet gösteren işletmedeki çalışanlar üzerindeki ergonomik risklerin potansiyel etkilerini araştırmak amacıyla tez çalışması yapmıştır. 47 mavi yakalı çalışan üzerinden gerçekleştirilen araştırmada, ergonomik riskler QEC yöntemi ile araştırılmıştır. Belirlenen ergonomik riskleri ortadan kaldırmak için iyileştirme önerileri sunulmuştur.

Çeşitli sektörlerde başarılı bir şekilde kullanılan QEC yönteminin, Sukadarin vd., (2013) tarafindan yapılan çalışmada, duruş pozisyonlarına ilişkin riskleri değerlendirmede yetersiz olduğu belirlenmiştir. Çalışmada palmiye yağı işçilerinin maruz kaldıkları ergonomik risk faktörleri, QEC yöntemi kullanarak tespit edilmeye çalışılmıştır. Palmiye yağ 1 işçilerinin, taze meyve salkımı toplarken birçok uygunsuz duruş problemlerine maruz kaldıkları gözlemlenmiştir. Araştırma sonucunda QEC yönteminde bacak değerlendirmesinin eksik olması, itme ve çekme değerlendirmesinin yapılmaması gibi kısıtların olduğu belirlenmiştir. Bu nedenlerden ötürü QEC yönteminin özellikle uzun ağaçlardaki meyveleri hasat sırasında ortaya çıkan duruşların analizinde yetersiz olduğu ifade edilmiştir.

QEC ölçeği ile işçilerin maruz kaldıkları risk düzeyi belirlenebilmektedir. Yöntem, ergonomik iyileştirme gereken işlerin sıralanmasına yardımcı olur ve uygulamaya konan ergonomik planın değerlendirmesine olanak sağlar. Hem çalışana hem de gözlemciye rehberlik eden yöntemde, gözlemciye ait 18, çalışana ait 25 madde bulunmaktadır. Maddelere verilen yanıtlardan bir puan tablosu oluşturulur. Maruziyetin düzeyleri puanlara göre belirlenir. Yöntem farklı iş kollarındaki çalışanların maruz kaldıkları riskleri değerlendirmek için kullanılabilmektedir (Özcan, 2011). QEC yönteminin uygulanması 5 adımda gerçekleşmektedir (G. Li ve Buckle, 2004):

- Eğitim,

- Gözlemcinin Kontrol Listesini Doldurması,

- Çalışanın Kontrol Listesini Doldurması,

- Maruziyet Puanlarının Hesaplanması,

- Eylemlerin Değerlendirilmesi

\section{Adım: Eğitim}

QEC yöntemi ilk kez kullanacakların kontrol listesinde kullanılan terminolojiyi ve değerlendirme kategorilerini anlaması için eğitilmesi gerekmektedir. Deneyimli kullanıcılar 1. adımı atlayabilir.

\section{Adım: Gözlemcinin Kontrol Listesini Doldurması}

QEC kullanıcısı (gözlemci) belirli bir görev için risk değerlendirmesini kontrol listesindeki "Gözlemcinin Değerlendirmesi” tarafını kullanarak gerçekleştirmektedir. Şekil 7'deki kontrol listesinde değerlendirme öğeleri açıkça belirtilmiştir. Değerlendirme yapılmadan önce en az bir tam çalışma döngüsü gözlemlenir. Bir iş çoklu görevlerden oluşuyorsa, her görev için ayrı ayrı değerlendirme yapılabilir. Bir iş kolaylıkla alt görevlere ayrılamıyorsa, söz konusu işin yapılması sırasında vücudun herhangi bir bölümüne en fazla yüklenmesine yani o işin içerisindeki “en kötü” durum gözlemlenmelidir. Değerlendirme doğrudan gözlem veya video görüntüleri kullanılarak yapılabilmektedir.

\section{Adım: Çalışanın Kontrol Listesini Doldurması}

2. adımda gözlemlenen çalışan Şekil 7'deki kontrol listesinin 'Çalışanın Değerlendirmesi' tarafını doldurur.

\begin{tabular}{|c|c|c|c|}
\hline \multicolumn{2}{|c|}{ GÖZLEMCİNIN DEĞERLENDİRMESİ } & \multicolumn{2}{|c|}{ ÇALIŞANIN DEĞERLENDİRMESİ } \\
\hline \multicolumn{2}{|c|}{ Sirt } & \multicolumn{2}{|c|}{ Çalıșanlar } \\
\hline $\mathbf{A}$ & Görev yapılırken bel (en kötü hali seçiniz): & $\mathbf{H}$ & Görev yapılırken elle kaldırdığınız en fazla ağırlık? \\
\hline A1 & Hemen hemen doğal mi? & H1 & Hafif (5 kg veya daha az) \\
\hline $\mathrm{A} 2$ & Orta derecede öne ya da yana eğilmiş veya dönmüş mü? & $\mathrm{H} 2$ & Orta $(6-10 \mathrm{~kg})$ \\
\hline A3 & Aşırı derecede öne ya da yana eğilmiş veya dönmüş mü? & $\mathrm{H} 3$ & Ağır (11-20) \\
\hline \multicolumn{2}{|c|}{ Aşağıdaki iki görev seçeneğinden YALNIZCA BİRİNİ seçiniz: } & $\mathrm{H} 4$ & Çok ağır (20 kg' den fazla) \\
\hline \multirow[t]{2}{*}{$\mathbf{B}$} & \multirow[t]{2}{*}{$\begin{array}{l}\text { 1)Ya sabit oturularak ya da ayakta yapılan görevler. Sırt } \\
\text { çoğunlukla sabit mi? }\end{array}$} & $\mathbf{J}$ & $\begin{array}{l}\text { Görevi yaparken günde ortalama ne kadar zaman } \\
\text { harcıyorsunuz? }\end{array}$ \\
\hline & & $\mathrm{J} 1$ & 2 saatten daha az \\
\hline B1 & Hayır & $\mathrm{J} 2$ & 2-4 saat \\
\hline $\mathrm{B} 2$ & Evet & $\mathrm{J} 3$ & 4 saatten daha fazla \\
\hline \multicolumn{2}{|c|}{$\begin{array}{l}\text { 2)Ya da kaldırma, itme/çekme, ve taşıma görevleri esnasında sırtın } \\
\text { hareketi: }\end{array}$} & $\mathbf{K}$ & Görev yapılırken, bir elle uygulanan en fazla güç? \\
\hline B3 & Nadiren (dakikada yaklaşık üç kez veya daha az) & K1 & Düşük (1 kg' dan az) \\
\hline B4 & Sık (dakikada yaklaşık sekiz kez) & K2 & Orta $(1-4 \mathrm{~kg})$ \\
\hline B5 & Çok sık (dakikada yaklaşık on iki kez veya daha fazla) & K3 & Yüksek (4 kg' den fazla) \\
\hline \multicolumn{2}{|c|}{ Omuz/Kol } & $\mathbf{L}$ & Görevin gerektirdiği görsel dikkat: \\
\hline $\mathbf{C}$ & Görev yapılırken eller (en kötü hali seçiniz): & L1 & Düşük (ince ayrıntı gerektirmiyor) \\
\hline $\mathrm{C} 1$ & Bel seviyesinde ya da daha aşağı mı? & $* \mathrm{~L} 2$ & Yüksek (bazı ince ayrıntılar görülmeli) \\
\hline $\mathrm{C} 2$ & Yaklaşık göğüs seviyesinde mi? & \multicolumn{2}{|c|}{ *Eğer yüksekse așağıda detayları belirtiniz. } \\
\hline $\mathrm{C} 3$ & Omuz seviyesinde veya daha yukarıda mı? & $\mathbf{M}$ & Görevde günlük taşıt kullanma süreniz: \\
\hline D & Omuz/kol hareketleri: & M1 & Bir saatten daha az ya da hiç mi? \\
\hline D1 & Nadiren (aralıklı) & M2 & Günde 1-4 saat mi? \\
\hline D2 & S1k (bazı duraklamalarla düzenli hareket) & M3 & Günde 4 saatten fazla mı? \\
\hline D3 & Çok sık (hemen hemen sürekli hareket) & $\mathbf{N}$ & Görevinizde titreșimli alet kullanma süreniz: \\
\hline \multicolumn{2}{|c|}{ Bilek/El } & N1 & Bir saatten daha az ya da hiç mi? \\
\hline
\end{tabular}




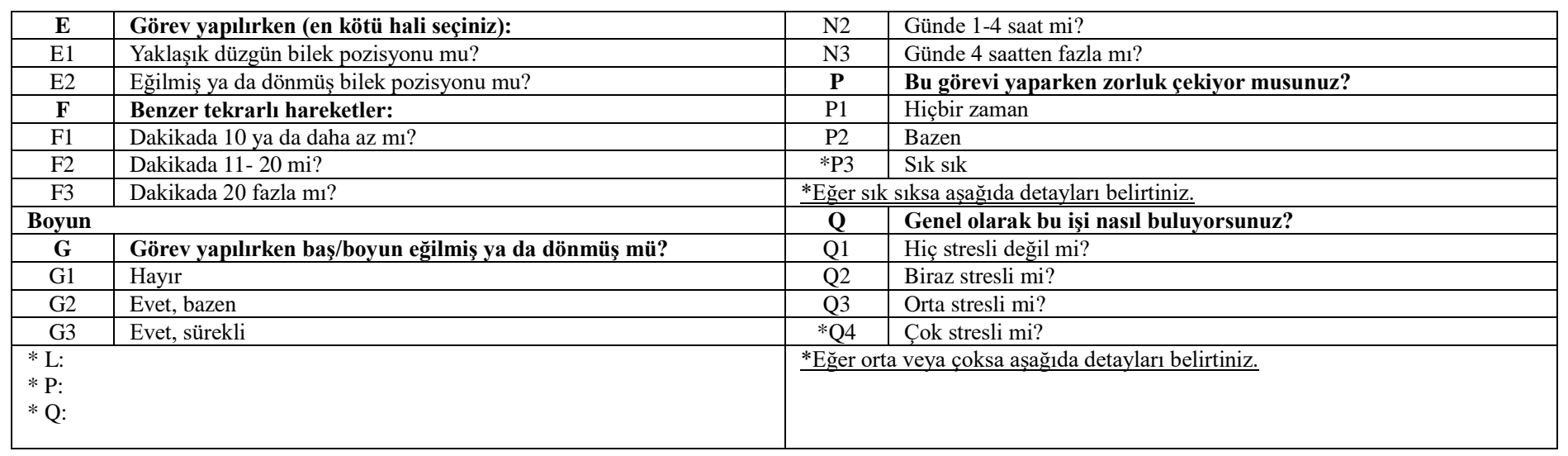

Şekil 4. Qec Yöntemi Kontrol Listesi (Koç ve Testik, 2016)

\section{Adım: Maruziyet Puanlarının Hesaplanması}

Maruziyet puanının hesaplanmasında Tablo 14'deki çizelge kullanılır ve değerlendirilen her bir görev için aşağıdaki adımlar gerçekleştirilir:

• “Gözlemci Değerlendirmesi” ve "Çalışan Değerlendirmesi” yanıtlarına karşılık gelen tüm harfler daire içine alınır.
- Daire içine alınmış her harf çiftinin kesişim noktasındaki sayılar işaretlenir ve bu sayılar harf çiftleri için ayrılan puan kutucuğuna yazılır.

- Puan kutucuklarına yazılan puanlar toplanarak sirt, omuz/kol, bilek/el ve boyun için toplam maruziyet puanları hesaplanır.

Tablo 14. Qec Yöntemi Maruziyet Puanı Çizelgesi (Koç ve Testik, 2016)

\begin{tabular}{|c|c|c|c|c|c|c|c|c|c|c|c|c|c|c|c|c|c|c|c|}
\hline \multicolumn{5}{|c|}{ Sirt } & \multicolumn{5}{|c|}{ Omuz/Kol } & \multicolumn{5}{|c|}{ Bilek/El } & \multicolumn{5}{|c|}{ Boyun } \\
\hline \multicolumn{5}{|c|}{ Sirt duruşu (A) ve Ağırlık (H) } & \multicolumn{5}{|c|}{ Yükseklik (C) ve Ağırlık (H) } & \multirow{2}{*}{\multicolumn{5}{|c|}{ Tekrarlı hareket (F) ve Kuvvet (K) }} & \multirow{2}{*}{\multicolumn{5}{|c|}{ Boyun duruşu $(\mathrm{G})$ ve Süre $(\mathrm{J})$}} \\
\hline \multirow[t]{2}{*}{ H1 } & A1 & $\mathrm{A} 2$ & A3 & \multirow{4}{*}{$\begin{array}{c}\text { Puan } \\
1\end{array}$} & & $\mathrm{C} 1$ & $\mathrm{C} 2$ & $\mathrm{C} 3$ & \multirow{4}{*}{$\begin{array}{c}\text { Puan } \\
1\end{array}$} & & & & & & & & & & \\
\hline & 2 & 4 & 6 & & $\mathrm{H} 1$ & 2 & 4 & 6 & & & F1 & $\mathrm{F} 2$ & F3 & Puan & & G1 & G2 & G3 & \multirow[t]{4}{*}{ Puan 1} \\
\hline $\mathrm{H} 2$ & 4 & 6 & 8 & & $\mathrm{H} 2$ & 4 & 6 & 8 & & $\mathrm{~K} 1$ & 2 & 4 & 6 & 1 & $\mathrm{~J} 1$ & 2 & 4 & 6 & \\
\hline H3 & 6 & 8 & 10 & & $\mathrm{H} 3$ & 6 & 8 & 10 & & K2 & 4 & 6 & 8 & & $\mathrm{~J} 2$ & 4 & 6 & 8 & \\
\hline $\mathrm{H} 4$ & 8 & 10 & 12 & & $\mathrm{H} 4$ & 8 & 10 & 12 & & K3 & 6 & 8 & 10 & & $\mathrm{~J} 3$ & 6 & 8 & 10 & \\
\hline \multicolumn{5}{|c|}{ Sırt duruşu (A) ve Süre $(\mathrm{J})$} & \multicolumn{5}{|c|}{ Yükseklik (C) ve Süre (J) } & \multicolumn{5}{|c|}{ Tekrarlı hareket $(\mathrm{F})$ ve Süre $(\mathrm{J})$} & \multicolumn{5}{|c|}{ Görsel dikkat $(\mathrm{L})$ ve Süre $(\mathrm{J})$} \\
\hline & A1 & $\mathrm{A} 2$ & A3 & \multirow{3}{*}{$\begin{array}{c}\text { Puan } \\
2\end{array}$} & & $\mathrm{C} 1$ & $\mathrm{C} 2$ & $\mathrm{C} 3$ & \multirow{3}{*}{$\begin{array}{c}\text { Puan } \\
2\end{array}$} & & F1 & $\mathrm{F} 2$ & F3 & \multirow{3}{*}{$\begin{array}{c}\text { Puan } \\
2\end{array}$} & & & G1 & $\mathrm{G} 2$ & \multirow[t]{3}{*}{ Puan 2} \\
\hline $\mathrm{J} 1$ & 2 & 4 & 6 & & $\mathrm{~J} 1$ & 2 & 4 & 6 & & $\mathrm{~J} 1$ & 2 & 4 & 6 & & & $\mathrm{~J} 1$ & 2 & 4 & \\
\hline $\mathrm{J} 2$ & 4 & 6 & 8 & & $\mathrm{~J} 2$ & 4 & 6 & 8 & & $\mathrm{~J} 2$ & 4 & 6 & 8 & & & $\mathrm{~J} 2$ & 4 & 6 & \\
\hline $\mathrm{J} 3$ & 6 & 8 & 10 & & $\mathrm{~J} 3$ & 6 & 8 & 10 & & $\mathrm{~J} 3$ & 6 & 8 & 10 & & & J3 & 6 & 8 & \\
\hline \multicolumn{5}{|c|}{ Süre $(J)$ ve Ağırlık $(H)$} & Süre & ve $\mathrm{A}$ & lik ( & & & Süre & ve $\mathrm{K}$ & vet ( & & & Bo. & için top & am pus & & \\
\hline H1 & $\mathrm{J} 1$ & $\mathrm{~J} 2$ & $\mathrm{~J} 3$ & Puan & & $\mathrm{J} 1$ & $\mathrm{~J} 2$ & $\mathrm{~J} 3$ & Puan & & & & & & Pue & ve puan & 2 toplar & & \\
\hline & 2 & 4 & 6 & 3 & $\mathrm{H} 1$ & 2 & 4 & 6 & 3 & & $\mathrm{~J} 1$ & $\mathrm{~J} 2$ & $\mathrm{~J} 3$ & Puan & & & & & \\
\hline $\mathrm{H} 2$ & 4 & 6 & 8 & & $\mathrm{H} 2$ & 4 & 6 & 8 & & $\mathrm{~K} 1$ & 2 & 4 & 6 & 3 & & & & & \\
\hline H3 & 6 & 8 & 10 & & $\mathrm{H} 3$ & 6 & 8 & 10 & & K2 & 4 & 6 & 8 & & & & & & \\
\hline $\mathrm{H} 4$ & 8 & 10 & 12 & & $\mathrm{H} 4$ & 8 & 10 & 12 & & K3 & 6 & 8 & 10 & & & & & & \\
\hline Elle & ima y & sa sa & ce 4' & & Sikl & D) $\mathrm{ve}$ & ğırlık & & & Bile & luruşu & ve & uvve & & Tas & ullanın & & & \\
\hline taşın & varsa & re 6 'y & saret & & & & & & & & & & & & & M1 & M2 & M3 & \\
\hline & atik & uş (B & e Sür & & & D1 & D2 & D3 & Puan & & & & & & & 1 & 4 & 9 & \\
\hline & & B1 & B2 & Puan & H1 & 2 & 4 & 6 & 4 & & & E1 & E2 & Puan & Tas & Illanım & için to & am p & an: \\
\hline & $\mathrm{J} 1$ & 2 & 4 & 4 & $\mathrm{H} 2$ & 4 & 6 & 8 & & & $\mathrm{~K} 1$ & 2 & 4 & 4 & Tit & & & & \\
\hline & $\mathrm{J} 2$ & 4 & 6 & & $\mathrm{H} 3$ & 6 & 8 & 10 & & & K2 & 4 & 6 & & & M1 & M2 & M3 & \\
\hline & $\mathrm{J} 3$ & 6 & 8 & & $\mathrm{H} 4$ & 8 & 10 & 12 & & & $\mathrm{~K} 3$ & 6 & 8 & & & 1 & 4 & 9 & \\
\hline Sikl & B) ve & Sirlik & & & Sikl & D) $\mathrm{ve}$ & üre $(\mathrm{J}$ & & & Bile & luruşu & ve & ire $(\mathrm{J}$ & & Tit & $n$ için $t$ & plam p & an: & \\
\hline H1 & B3 & B4 & B5 & Puan & & & & & Puan & & & & & & İş & osu & & & \\
\hline & 2 & 4 & 6 & 5 & & D1 & D2 & D3 & 5 & & & E1 & E2 & Puan & & P1 & $\mathrm{P} 2$ & P3 & \\
\hline $\mathrm{H} 2$ & 4 & 6 & 8 & & $\mathrm{~J} 1$ & 2 & 4 & 6 & & & $\mathrm{~J} 1$ & 2 & 4 & 5 & & 1 & 4 & 9 & \\
\hline H3 & 6 & 8 & 10 & & $\mathrm{~J} 2$ & 4 & 6 & 8 & & & $\mathrm{~J} 2$ & 4 & 6 & & İş t & osu içi & toplan & puan: & \\
\hline $\mathrm{H} 4$ & 8 & 10 & 12 & & $\mathrm{~J} 3$ & 6 & 8 & 10 & & & $\mathrm{~J} 3$ & 6 & 8 & & Str & & & & \\
\hline S1kl & A) ve & ire $(\mathrm{J}$ & & & Om & Kol i & pua & opla & & Bile & El içiı & uan & blam & & Q & Q2 & Q3 & $\mathrm{Q} 4$ & \\
\hline & B3 & $\mathrm{B} 4$ & B5 & Puan & 1 'de & 'e tüı & uanl & & & 1 'de & 5'e tü & puanl & & & 1 & 4 & 9 & 16 & \\
\hline J1 & 2 & 4 & 6 & 6 & & & & & & & & & & & Str & in topl & m puan & & \\
\hline $\mathrm{J} 2$ & 4 & 6 & 8 & & & & & & & & & & & & & & & & \\
\hline $\mathrm{J} 3$ & 6 & 8 & 10 & & & & & & & & & & & & & & & & \\
\hline $\begin{array}{l}\text { Surt } \\
\text { 1'de } \\
\text { veya } \\
\text { topla }\end{array}$ & $\begin{array}{l}\text { n top } \\
\text { e ka } \\
\text { den } 3 \\
:\end{array}$ & $\begin{array}{l}\text { pua } \\
\text { puar } \\
5 \mathrm{~V}\end{array}$ & n to & & & & & & & & & & & & & & & & \\
\hline
\end{tabular}


Tablo 15. Qec yöntemi eylem seviyeleri (Rahma ve Faiz, 2019)

\begin{tabular}{|c|c|c|c|}
\hline QEC Puanı & Risk Seviyesi & Eylem Seviyesi & Önlem \\
\hline$\leq \mathbf{4 0 \%}$ & Düşük & 0 & Kabul Edilebilir \\
\hline $41-50 \%$ & Orta & 1 & Daha Fazla İncelenmeli \\
\hline $51-70 \%$ & Yüksek & 2 & Daha Fazla İncelenmeli ve Değişiklik Yapılmalı \\
\hline$>70 \%$ & Çok Yüksek & 3 & İncelenmeli ve Acilen Değişiklik Yapıllmalı \\
\hline
\end{tabular}

\section{Adım: Eylemlerin Değerlendirilmesi}

Her bir vücut bölümü için maruziyet puanları hesaplandiktan sonra genel maruziyet seviyesi (E) puanı hesaplanmaktadır. Elle taşıma olan ve olmayan görevler için iki farklı E puanı hesaplanmaktadır. E puanının yüzdelik değeri, değerlendirme sonucunda hesaplanan puanın (X), muhtemel en büyük toplam puana (Xmax) bölünmesi ile elde edilmektedir. Hesaplanan E puanı için Tablo 15'de belirtilen önlemler dikkate alınarak uygulamalar yapılmaktadır. Elle taşıma görevleri için $\mathrm{XmaxMH}=176$, elle taşıma olmayan görevler için $\mathrm{Xmax}=$ 162 'dir.

$$
\mathrm{E}(\%)=\mathrm{X} / \mathrm{X} \max \times 100 \%(\text { Koç ve Testik, 2016) }
$$

\section{Civata Fabrikasında Ergonomik Risklerin Değerlendirilmesi Üzerine Bir Uygulama}

$\mathrm{Bu}$ çalışmanın uygulama kısmında Malatya 2. Organize sanayinde cıvata imalatı yapan bir fabrikada ergonomik risk değerlendirme yöntemleri aracılığıyla bir araştırma gerçekleştirilmiştir.

\subsection{Araştırmanın Amacı ve Önemi}

İmalat işletmelerinde çalışanın verimliliğine olumsuz etkileri olan birçok problemle karşılaşılabilmektedir. $\mathrm{Bu}$ problemlerin belirlenmesi ve çözülmesi, hem iş gören hem de işveren memnuniyeti açısından büyük önem taşımaktadır. $\mathrm{Bu}$ çerçevede, Malatya 2. Organize sanayinde cıvata imalatı yapan bir fabrikada çalışanlarda kas ve iskelet zorlanmasına sebep olan süreçleri, ergonomik risk değerlendirme yöntemleri aracılığıyla incelemek, ergonomik açıdan riskli uygulamaları belirlemek ve bu uygulamaların iyileştirilmesine yönelik çalışan verimliliğini artırabilecek öneriler sunmak çalışmanın ana amaçları arasindadir.

$\mathrm{Bu}$ çalışma, fabrikadaki verimliliğe olumsuz yönde etki eden ergonomik risklerin belirlenmesi ve iyileştirmesine yönelik önerilerin geliştirilebilmesi açısından önemli olacaktır. $\mathrm{Bu}$ çalışmayla fabrika, eksiklerini görme ve iyileştirme firsatı bulacaktır. Ayrıca çalışma benzer fabrikalar için problemlere sistematik yaklaşım açısından örnek olma özelliği taşıyacaktır.

Ergonomik risklerin değerlendirilmesi üzerine yapılan çalışmalar incelendiğinde ergonomik risk unsurları bir veya iki yöntemle incelenmiştir. Ayrıca önceki çalışmalarda gözleme dayalı fotoğraflama yöntemleriyle veriler toplanmaya çalışılmıştır. Bu tür incelemeler anlık gözlemle olduğu için çalışanlarda baskı oluşturmakta ve gözlemciyi yanıltabilmektedir. Bununla birlikte gözlemci üzerinde iş yerindeki çevresel koşullar ve kısa çevrim süreleri nedeniyle baskı artacak, ölçümde, kayıtta ve hesaplamada hatalar ortaya çıkabilecektir. Bu çalışmada ise risk unsurlarının birden fazla yöntemle değerlendirilmesi ve kamerayla incelemelerin yapılması çalışmanın özgün değerini oluşturmaktadır. Malatya sanayinde benzer bir çalışmaya rastlanmamış olması çalışmanın diğer işletmeler için de farkındalık oluşturması açısından son derece önemlidir. Bununla beraber, uygulamanın gerçekleştirildiği işletmede problemlerin belirlenmesi ve analizlerin yapılması sistematik olarak ele alındığından farklı sektörlerde de uygulanabilecek bir model ortaya çıkmaktadır. $\mathrm{Bu}$ çerçevede modelin hem literatüre hem de bölgesel ekonominin gelişmesine katkı sağlayacağını ifade etmek mümkündür.

\subsection{Araștırmanın Yöntemi ve Kısıtları}

Araştırmada belirlenen amaçlara ulaşabilmek için nitel ve nicel yöntemler kullanılmıştır. Uygulanabilirlik ve operasyonların fazlalığı açısından bütün bölümlerde bir risk değerlendirmesinin yapılması mümkün olmamıştır. Bu nedenle emeğin en yoğun olduğu tel çekme bölümünün seçilmesi araştırmada bir kısıt oluşturmuştur.

Nitel yöntem kapsamında mevcut durumun analiz edilmesine ve problemlerin belirlenmesine yönelik keşfedici bir araştırma yürütülmüştür. Keşfedici araştırma sürecinde, tel çekme bölümünde yer alan bütün süreçlerde gözlemler gerçekleştirilmiş, başta üst düzey yetkililer olmak üzere ilgili çalışanlarla görüşmeler yapılmıştır. Yine sistemin öğrenilmesi ve mevcut durumun daha iyi analiz edilebilmesi için dokümantasyon incelemeleri yapılmıştır. 


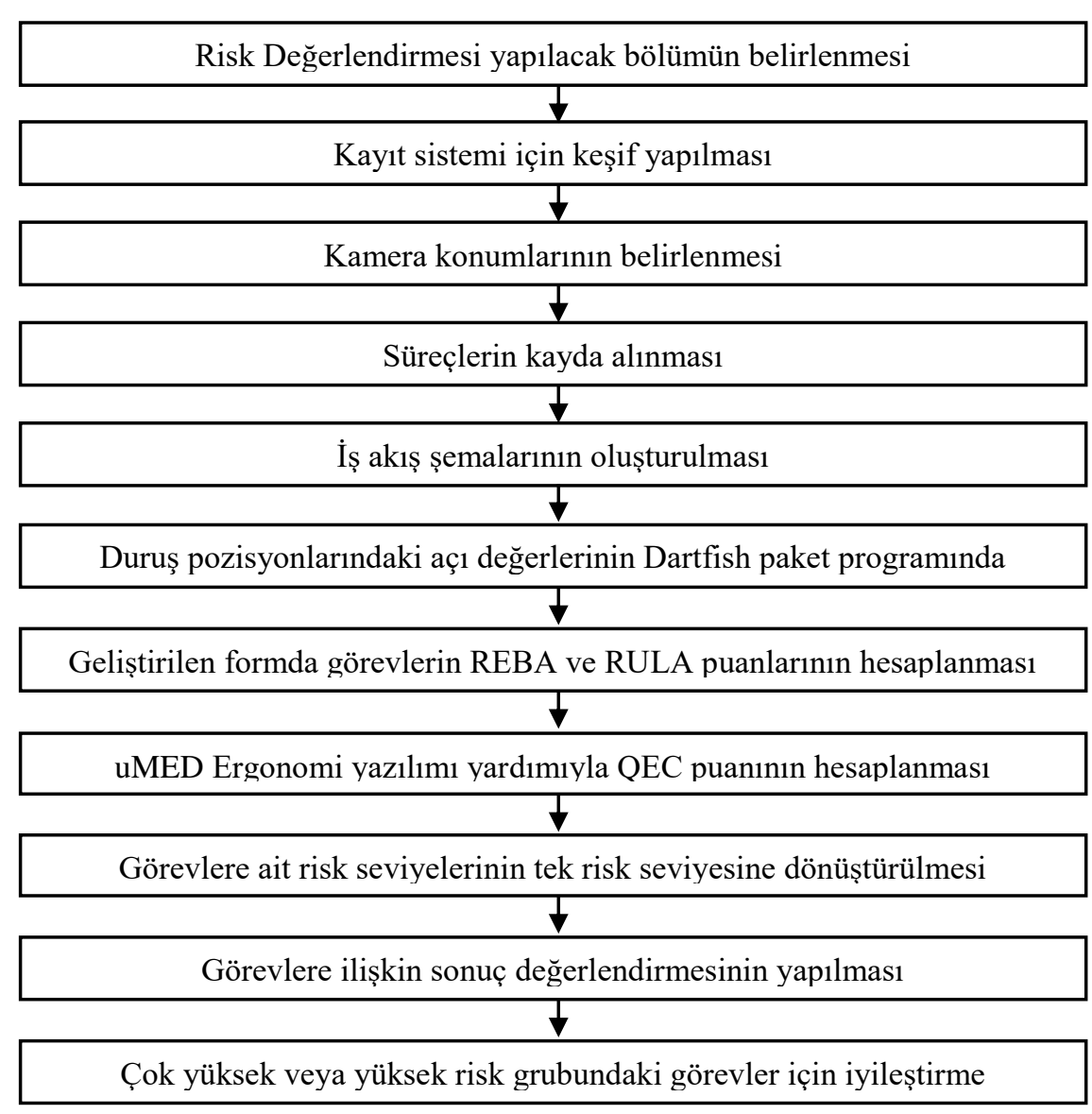

\section{Şekil 8. Uygulama Modeli}

Nicel yöntem kapsamında ise REBA RULA ve QEC yöntemleri ile duruş pozisyonlarının risk değerlendirilmesi yapılmıştır. Bu çerçevede video kamerası ile kayıt altına alınan süreçler, ofis ortamında izlenip değerlendirilmiştir. Kayıtlarda iş yapımı esnasında ortaya çıkan duruşlar, ekran fotoğrafı alınarak incelenmiştir. Ekran fotoğraflarında yer alan duruşlara ilişkin kol, bacak, boyun ve bel açı değerleri, Dartfish paket programı yardımıyla hesaplanmıştır. REBA ve RULA yöntemlerinde duruşlara ilişkin tekrar sayıları göz ardı edilmekte ve çalışan görüşleri yer almamaktadır. Bu nedenle duruş sıklığını ve çalışanın görüşünü dikkate alan QEC yöntemi üçüncü bir yöntem olarak kullanılmıştır. RULA ve REBA puanları hazırlanan şablon yardımıyla hesaplanırken, QEC puanları uMED Ergonomi yazılımının kullanımıyla hesaplanmıştır. Çalışmada kullanılan uygulama modeli Şekil 8'deki gibidir.

\subsection{Mevcut Durum Analizi}

İşletme, Malatya 2. Organize Sanayi Bölgesi'nde bağlantı elemanları sektöründe faaliyet göstermektedir. $39.379 \mathrm{~m} 2$ arazi üzerine kurulu olan işletmenin 18.571 m2 kapalı alanı bulunmaktadır. İşletme, 2020 yılı itibari ile 224 çalışanla, aylık ortalama 762 ton üretim gerçekleştirmektedir.

Araştırma kapsamında ele alınan tel çekme bölümünde ise 9 çalışanla günlük ortalama 40-45 ton tel çekimi gerçekleştirilmektedir. 4,5-28 mm çap aralığında ve farklı özelliklerde kangal haldeki teller, tel çekme bölümünde istenen özelliklere göre çekilerek cıvata, vida ve somun üretimi için hazır hale getirilmektedir.

Kapasite kullanım oranı üretim planlama açısından büyük öneme sahiptir. Kapasite kullanım oranı fiili kapasitenin normal kapasite içerisindeki yüzdelik oranı ile belirlenebilmektedir. Fiili kapasite miktarı fabrika genelinde günlük ortalama 30 ton, tel çekme bölümünde günlük ortalama 40-45 ton olarak gerçekleşmektedir. Normal kapasite miktarlarına bakıldığında ise fabrika genelinde 51 ton, tel çekme bölümünde yaklaşık 200225 ton olarak hesaplanmaktadır. Bu rakamlardan kapasite kullanım oranları hesaplandığında fabrika genelinde \%60 iken, tel çekme bölümünde $\% 20$ olduğu görülmektedir. Tel çekme bölümünde fabrika geneline göre düşük kapasite ile çalışılması insan gücü kapasitesinden ve talep miktarından kaynaklanmaktadır.

Fabrika ortamında yaşanan iş kazaları, çalışanların motivasyon ve performanslarının düşmesine, işverenlerin ise tazminat ve sağlık giderleri gibi çeşitli maliyetlerle karşı karşıya kalmasına neden olmaktadır. Özellikle emeğin yoğun olduğu işletmelerde iş kazaları daha fazla yaşanmaktadır. Her işletmede olduğu gibi bu fabrikada da zaman zaman iş kazaları yaşanmaktadır. Fabrika genelinde 2019 yılı itibariyle $29 \mathrm{kez}$ iş kazası yaşanmış ve bu iş kazalarında toplamda 135 gün iş göremezlik raporu alınmıştır. Tel çekme bölümündeki rakamlara bakıldığında ise yıllık yaklaşık 4-5 defa iş kazası yaşanmış ve bu iş kazaları sebebiyle ortalama 19 gün iş göremezlik raporu alınmıştır.

\subsection{Risklerin Değerlendirilmesi}

Mevcut durum analizi sürecinde tanımlamaları yapılan görevlere ilişkin risklerin değerlendirilmesi, araştırma kapsamında belirlenen REBA, RULA ve QEC yöntemleriyle gerçekleştirilmiştir. Değerlendirilmelerin yapıldığ görevlere ait formlar Şekil 9'daki gibi oluşturulmuştur. 


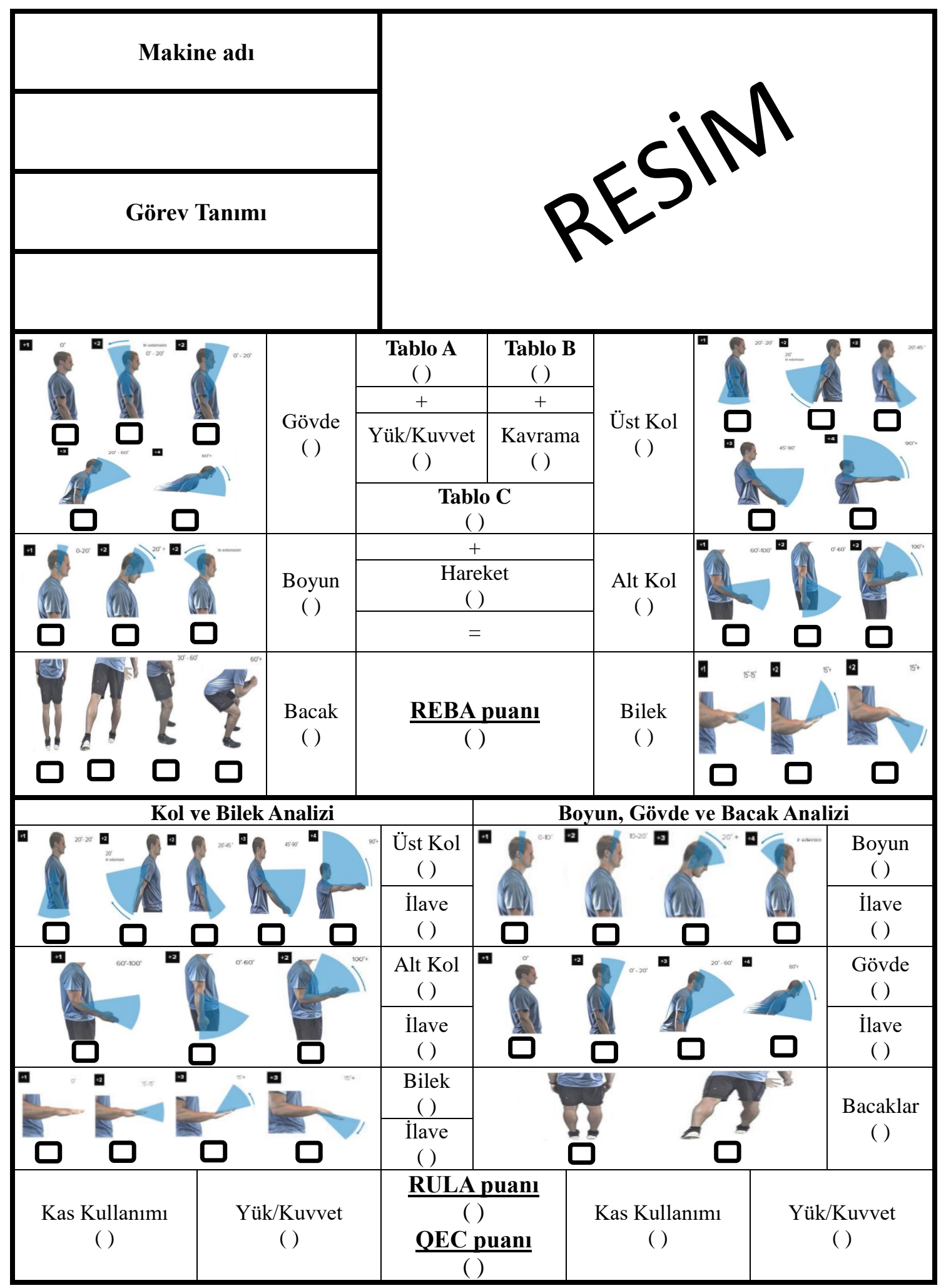

Şekil 9. Geliştirilen Değerlendirme Formu

55 göreve ilişkin yapılan değerlendirme sonuçlarının özeti

Tablo 16'da verilmiştir. 
Tablo 16. Görevlerin Risk Değerlendirme Yöntemlerindeki Puan Dă̆llımları

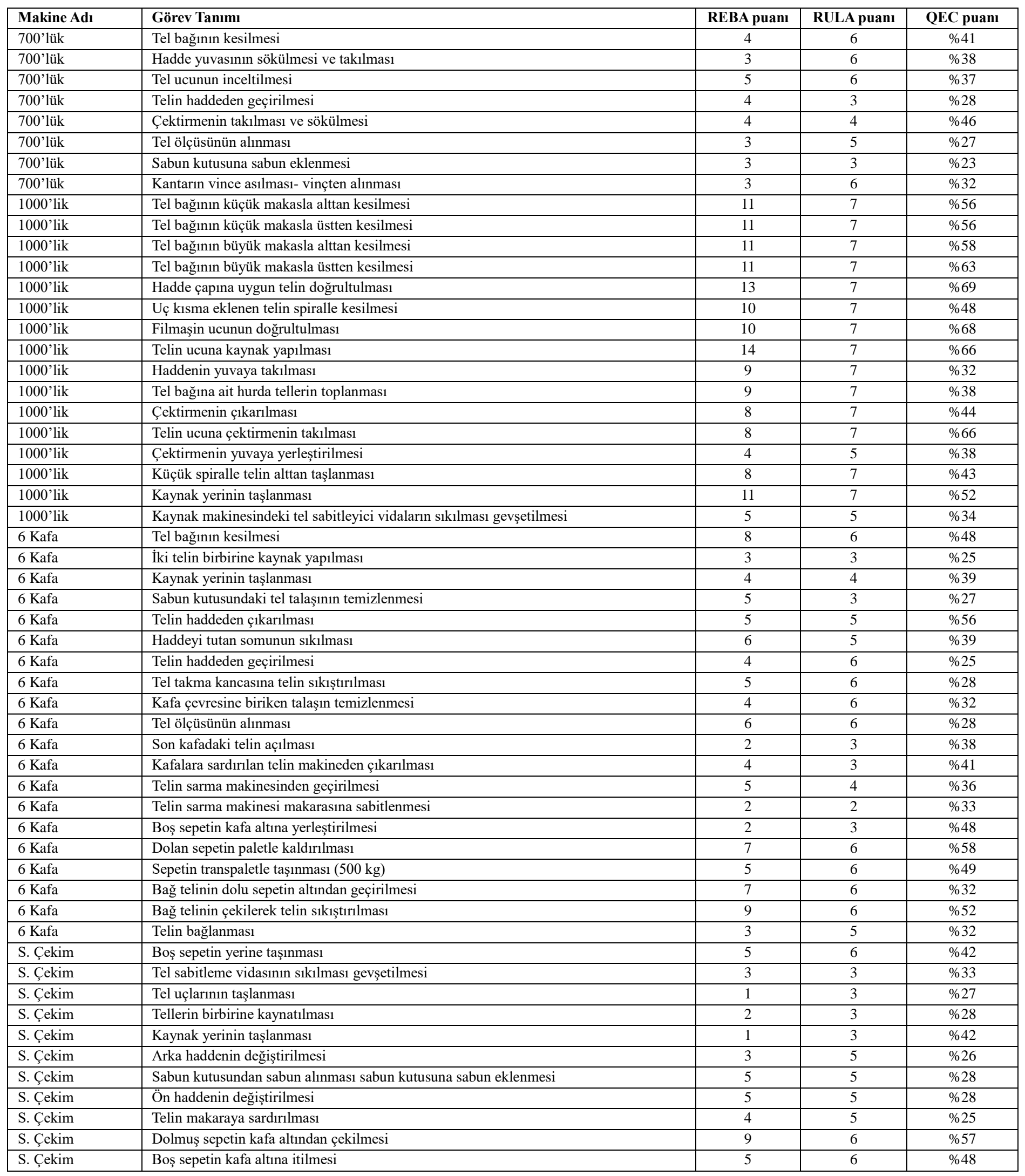

\subsubsection{Yöntemlerin Karşılaştırılması ve Sonuç Değerlendirmesi}

Araştırmada görevler üç farklı yöntemle değerlendirmeye tabi tutulduğundan sonuç değerlendirmesinin yapılabilmesi için sistematik bir yöntem geliştirilmiştir. Öncelikli olarak risk değerlendirme yöntemlerinden elde edilen puanlar risk seviyesi şeklinde ifade edilmiştir. Puanlara karşılık gelen seviyeleri Tablo 17 'de verilmiştir. 
European Journal of Science and Technology

Tablo 17. Risk Değerlendirme Yöntemlerinin Puanlarına Göre Risk Seviyeleri

\begin{tabular}{|c|c|c|c|}
\hline Risk Seviyesi & REBA Puanı & RULA Puanı & QEC Puanı \\
\hline Düşük Risk & $1-3$ & $1-2$ & $0-40 \%$ \\
\hline Orta Risk & $4-7$ & $3-4$ & $41-50 \%$ \\
\hline Yüksek Risk & $8-10$ & $5-6$ & $51-70 \%$ \\
\hline Çok Yüksek Risk & $11-15$ & 7 & $71-100 \%$ \\
\hline
\end{tabular}

Sonrasında hesaplanan üç risk seviyesi bir risk seviyesine dönüştürülmüştür. Dönüştürmede iki farklı değerlendirme yaklaşımı kullanılmıştır. Birinci yaklaşımda salt çoğunluğa göre karar verme yöntemi benimsenmiştir. Örneğin, bir görev için risk seviyesinin REBA' da "Çok Yüksek", RULA' da "Çok Yüksek” ve QEC' de “Yüksek” olması durumda göreve ilişkin risk seviyesi "Çok Yüksek" olarak kabul edilmiştir. İkinci yaklaşımda ise üç farklı yöntem, farklı risk seviyesini gösteriyorsa ortadaki risk seviyesi dikkate alınmıştır. Örneğin, göreve ilişkin risk seviyesi REBA' da "Çok Yüksek", RULA' da "Yüksek" ve QEC' de "Orta" çıkması durumunda, risk seviyesi "Yüksek" olarak kabul edilmiştir. ÇYR, YR, OR, DR.

Tablo 18. Sonuç Değerlendirmesi

\begin{tabular}{|c|c|c|c|c|c|}
\hline Makine Adı & Görev Tanımı & REBA & RULA & QEC & $\begin{array}{c}\text { Sonuç } \\
\text { Değerlendirmesi }\end{array}$ \\
\hline 1000’lik & Tel bağının küçük makasla üstten kesilmesi & ÇYR & ÇYR & YR & ÇYR \\
\hline 1000’lik & Tel bağının büyük makasla üstten kesilmesi & ÇYR & ÇYR & YR & ÇYR \\
\hline 1000’lik & Hadde çapına uygun telin doğrultulması & ÇYR & ÇYR & YR & ÇYR \\
\hline 1000’lik & Telin ucuna kaynak yapılması & ÇYR & ÇYR & YR & ÇYR \\
\hline 1000’lik & Filmaşin ucunun doğrultulması & YR & ÇYR & YR & YR \\
\hline 1000’lik & Haddenin yuvaya takılması & YR & ÇYR & DR & YR \\
\hline 1000’lik & Tel bağına ait hurda tellerin toplanması & YR & ÇYR & DR & YR \\
\hline 1000’lik & Çektirmenin çıkarılması & YR & ÇYR & OR & YR \\
\hline 1000’lik & Telin ucuna çektirmenin takılması & YR & ÇYR & YR & YR \\
\hline $6 \mathrm{Kafa}$ & Bağ telinin çekilerek telin sıkıştırılması & YR & YR & YR & YR \\
\hline S. Çekim & Dolmuş sepetin kafa altından çekilmesi & YR & YR & YR & YR \\
\hline $700^{\prime} l u ̈ k$ & Tel bağının kesilmesi & OR & YR & OR & OR \\
\hline 700'lük & Tel ucunun inceltilmesi & $\overline{\mathrm{OR}}$ & $\overline{\mathrm{YR}}$ & $\overline{\mathrm{DR}}$ & OR \\
\hline $700^{\prime} l u ̈ k$ & Telin haddeden geçirilmesi & $\overline{\mathrm{OR}}$ & OR & $\mathrm{DR}$ & OR \\
\hline $700^{\prime} l u ̈ k$ & Çektirmenin takılması ve sökülmesi & OR & OR & OR & OR \\
\hline 1000’lik & Çektirmenin yuvaya yerleştirilmesi & $\mathrm{OR}$ & YR & $\mathrm{DR}$ & $\mathrm{OR}$ \\
\hline 1000’lik & Kaynak makinesindeki tel sabitleyici vidaların sıkılması-gevşetilmesi & $\overline{\mathrm{OR}}$ & $\overline{\mathrm{YR}}$ & $\overline{\mathrm{DR}}$ & OR \\
\hline 6 Kafa & Kaynak yerinin taşlanması & $\mathrm{OR}$ & $\mathrm{OR}$ & DR & $\mathrm{OR}$ \\
\hline $6 \mathrm{Kafa}$ & Sabun kutusundaki tel talaşının temizlenmesi & $\overline{\mathrm{OR}}$ & OR & DR & OR \\
\hline $6 \mathrm{Kafa}$ & Haddeyi tutan somunun sıkılması & OR & YR & $\mathrm{DR}$ & OR \\
\hline 6 Kafa & Bağ telinin dolu sepetin altından geçirilmesi & $\overline{\mathrm{OR}}$ & YR & DR & OR \\
\hline Son Çekim & Boş sepetin yerine taşınması & $\overline{\mathrm{OR}}$ & YR & OR & OR \\
\hline Son Çekim & Kaynak yerinin taşlanması & $\overline{\mathrm{DR}}$ & $\mathrm{OR}$ & OR & $\mathrm{OR}$ \\
\hline Son Çekim & Sabun kutusundan sabun alınması - sabun kutusuna sabun eklenmesi & $\mathrm{OR}$ & YR & DR & $\mathrm{OR}$ \\
\hline Son Çekim & Ön haddenin değiştirilmesi & $\mathrm{OR}$ & YR & DR & $\mathrm{OR}$ \\
\hline Son Çekim & Telin makaraya sardırılması & $\overline{\mathrm{OR}}$ & YR & DR & OR \\
\hline Son Çekim & Boş sepetin kafa altına itilmesi & $\overline{\mathrm{OR}}$ & YR & OR & $\mathrm{OR}$ \\
\hline
\end{tabular}




\begin{tabular}{|c|c|c|c|c|c|}
\hline Makine Adı & Görev Tanımı & REBA & RULA & QEC & $\begin{array}{c}\text { Sonuç } \\
\text { Değerlendirmesi }\end{array}$ \\
\hline 700'lük & Tel ölçüsünün alınması & DR & YR & DR & $\overline{\mathrm{DR}}$ \\
\hline 700'lük & Kantarın vince asılması- vinçten alınması & $\overline{\mathrm{DR}}$ & $\overline{\mathrm{YR}}$ & $\overline{D R}$ & $\overline{\mathrm{DR}}$ \\
\hline $6 \mathrm{Kafa}$ & İki telin birbirine kaynak yapılması & $\overline{D R}$ & $\overline{\mathrm{OR}}$ & $\overline{D R}$ & $\overline{\mathrm{DR}}$ \\
\hline $6 \mathrm{Kafa}$ & Son kafadaki telin açılması & $\overline{\mathrm{DR}}$ & $\overline{\mathrm{OR}}$ & DR & $\overline{\mathrm{DR}}$ \\
\hline Son Çekim & Tel sabitleme vidasının sıkılması-gevşetilmesi & DR & $\overline{\mathrm{OR}}$ & DR & $\overline{\mathrm{DR}}$ \\
\hline Son Çekim & Tel uçlarının taşlanması & DR & $\overline{\mathrm{OR}}$ & DR & $\overline{\mathrm{DR}}$ \\
\hline Son Çekim & Tellerin birbirine kaynatılması & DR & $\overline{\mathrm{OR}}$ & $\overline{D R}$ & $\overline{\mathrm{DR}}$ \\
\hline Son Çekim & Arka haddenin değiştirilmesi & DR & YR & DR & $\overline{\mathrm{DR}}$ \\
\hline
\end{tabular}

Sonuç değerlendirmesinde ortaya çıkan risk seviyelerine göre makinelerdeki görev sayılarına ilişkin bilgiler Tablo 19'da gösterilmiştir. Tablo 19'a göre düşük riskte 12, orta riskte 24, yüksek riskte 12, çok yüksek riskte 7 görev tespit edilmiştir. Çok yüksek risk sadece 1000'lik makinede görülmüştür.

Tablo 19. Risk Seviyelerine Göre Makinelerdeki Görev Sayıları

\begin{tabular}{|c|c|c|c|c|c|}
\hline Risk Seviyesi & 1000 'lik & 700 'lük & Altı Kafa & Son Çekim & Toplam \\
\hline Düşük Risk & - & 4 & 4 & 4 & $\mathbf{1 2}$ \\
\hline Orta Risk & 2 & 4 & 12 & 6 & $\mathbf{2 4}$ \\
\hline Yüksek Risk & 7 & - & 4 & 1 & $\mathbf{1 2}$ \\
\hline Çok Yüksek Risk & 7 & - & - & - & $\mathbf{7}$ \\
\hline Toplam & $\mathbf{1 6}$ & $\mathbf{8}$ & $\mathbf{2 0}$ & $\mathbf{1 1}$ & $\mathbf{5 5}$ \\
\hline
\end{tabular}

Makine bazında görevlerin yüzdelik olarak risk dağılımları Şekil 10'da verilmiştir. Şekil 10' daki grafikler incelendiğinde, 1000'lik makinedeki görevlerin \%44'ünün çok yüksek, $\% 44$ 'ünün yüksek, geriye kalan \%12'sinin ise orta risk seviyesinde olduğu görülmektedir. Ayrıca bu makinede düşük risk seviyesine rastlanmamıştır. 700'lük makineye bakıldığında, görevlerin \%50'sinin orta, \%50'sinin düşük seviyede risk içerdiği görülmektedir. Altı kafa makinesindeki risk değerlendirmesine ilişkin oranlara bakıldığında, görevlerin \%60'ının orta risk, \%20'sinin yüksek risk geriye kalan $\% 20$ 'sinin ise düşük risk grubunda olduğu görülmektedir. Son olarak son çekim makinesine bakıldığında, görevlerin \%55'inin orta risk, \%36'sının düşük risk ve \%9'unun yüksek risk içerdiği görülmektedir.
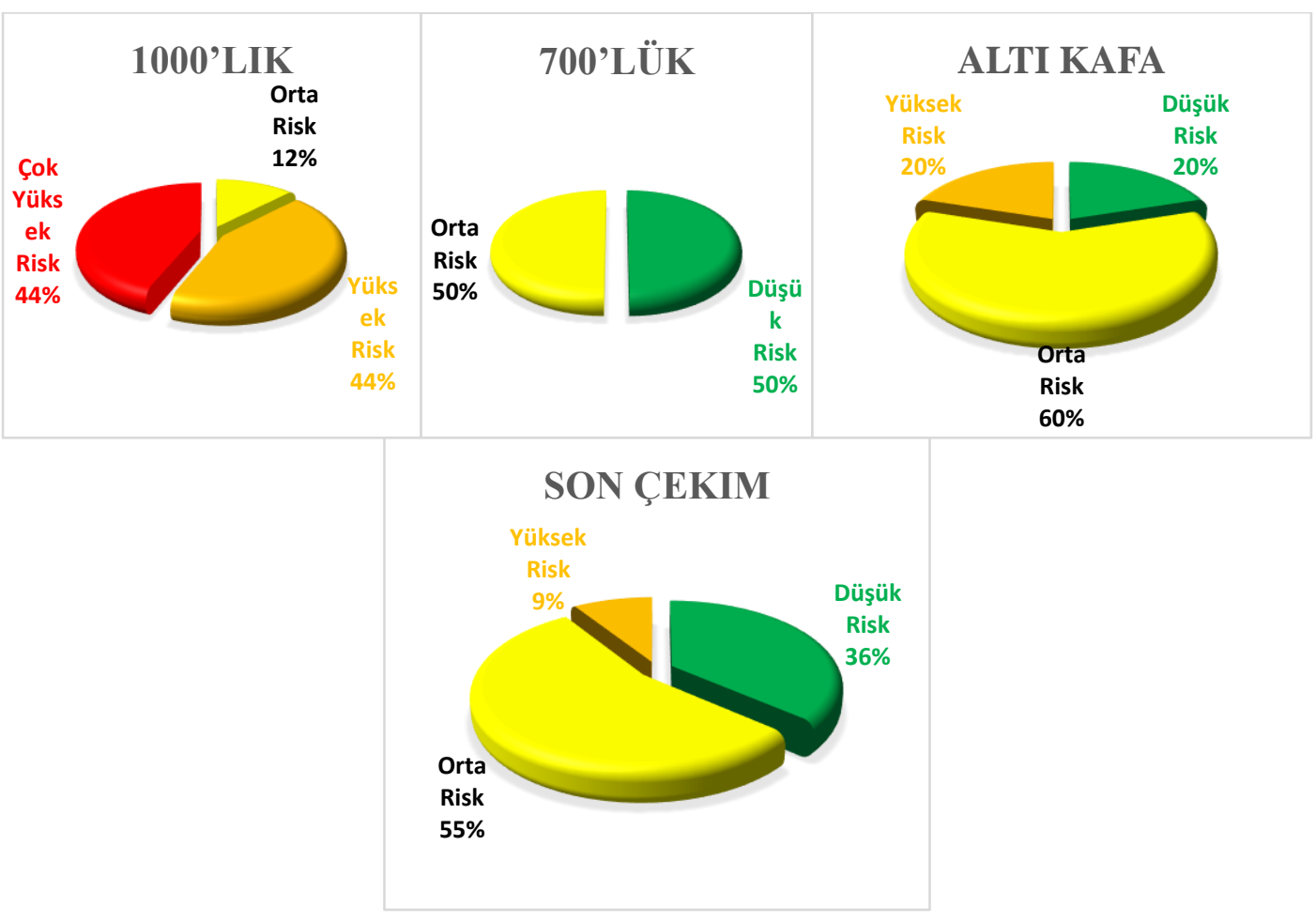

Şekil 10. Makine Bazında Risk Dağıllımları 


\subsection{Genel Değerlendirme ve İyileștirme Önerileri}

Yapılan çalışmada, RULA, REBA ve QEC yöntemi tel çekme bölümündeki çalışan personelin çalışma duruşlarını değerlendirmek için kullanılmıştır. 1000'lik, 700'lük, altı kafa ve son çekim makinelerindeki tel çekme süreçlerinde yer alan 55 görev üç farklı yöntemle tek tek değerlendirilmiştir. Görevlere ilişkin nihai risk seviyesi belirlenirken yöntemlere ait sonuçlarda benzerlik olması durumunda en az iki yöntemin belirttiği risk seviyesi, yöntemlere ait sonuçlarda farklılık olması durumunda ise üç yöntemin belirttiği ortalama risk seviyesi dikkate alınmıștır. Görevlerin genel risk dağılımları Şekil 11'de verilmiştir. Şekil 11 incelendiğinde görevlerin \%43'ünün orta risk, $\% 22$ 'sinin yüksek risk, $\% 22$ 'sinin düşük risk ve $\% 13$ 'ünün çok yüksek risk grubunda olduğu görülmektedir. Görevlerin toplamda $\% 35$ 'i çok yüksek ve yüksek risk grubunda yer almaktadır. Bu sonuç söz konusu görevlerin kısa süre içerisinde veya acilen iyileştirilmesi gerektiğine işaret etmektedir. $\mathrm{Bu}$ görevlerden özellikle 1000'lik makinedeki görevler çok yüksek risk grubundaki görevlerin tamamını ve yüksek risk grubundaki görevlerin yarıdan fazlasını oluşturmaktadır. 1000'lik makineyi risk fazlalığı bakımından altı kafa makinesi, son çekim ve 700 'lük makine takip etmektedir. $\mathrm{Bu}$ sebeple tel çekme bölümündeki personelin kas ve iskelet sistemi üzerindeki zorlanma büyükten küçüğe 1000 'lik, altı kafa, son çekim ve 700'lük şeklinde yaşanmaktadır.

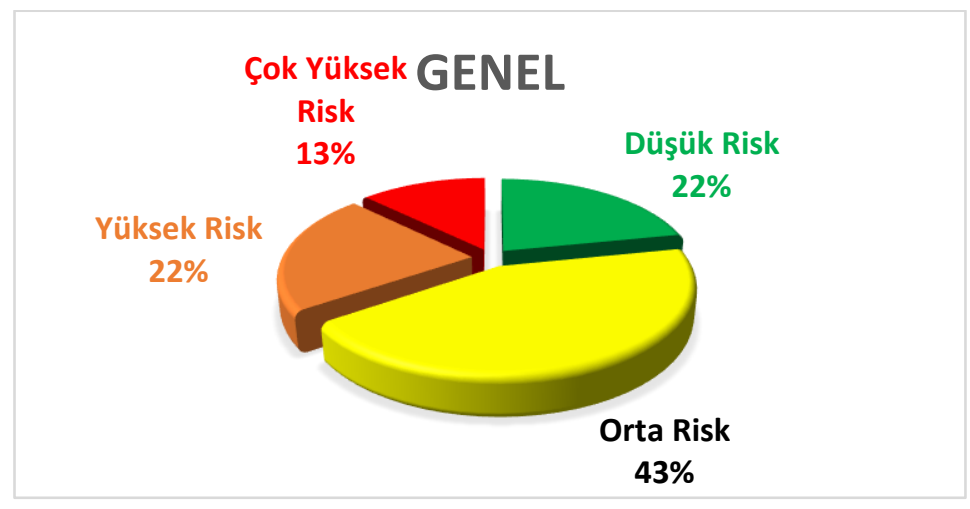

Şekil 11 Görevlerin Ortalama Risk Dağıllimları

Analiz sonuçlarına göre mevcut durum ve iyileştirme önerileri aşağıdaki gibidir:

- Yapılan değerlendirmede, 1000'lik makinedeki tel bağının makasla kesilme işlemi çalışanların kas ve iskelet sistemi üzerinde zorlanmanın en fazla olduğu görevlerden birisidir. Çalışan, filmaşin alt tarafındaki tel bağını keserken eğilmekte, üst taraftaki tel bağını keserken makası omuz hizasında tutmaktadır. Kalın çaplı teli tutan mukavemeti yüksek bağ telinin kesim işlemi her ne kadar el aleti ile yapılıyor olsa da çalışanı zorlamakta ve kullanılan kesme makasının tel kesiminde yetersiz kaldığı görülmektedir. $\mathrm{Bu}$ sebeple tel bağının kesilmesi işleminin hidrolik el makası ile yapılması önerilmektedir. İyileştirme önerisine ait görsel Şekil 12'de verilmiştir. Bu uygulama ile çalışanın kesme esnasındaki çabasının ortadan kalkacağı, zorlanmanın en aza inebileceği ve işlemin daha hızlı bir şekilde gerçekleştirilebileceği düşünülmektedir.

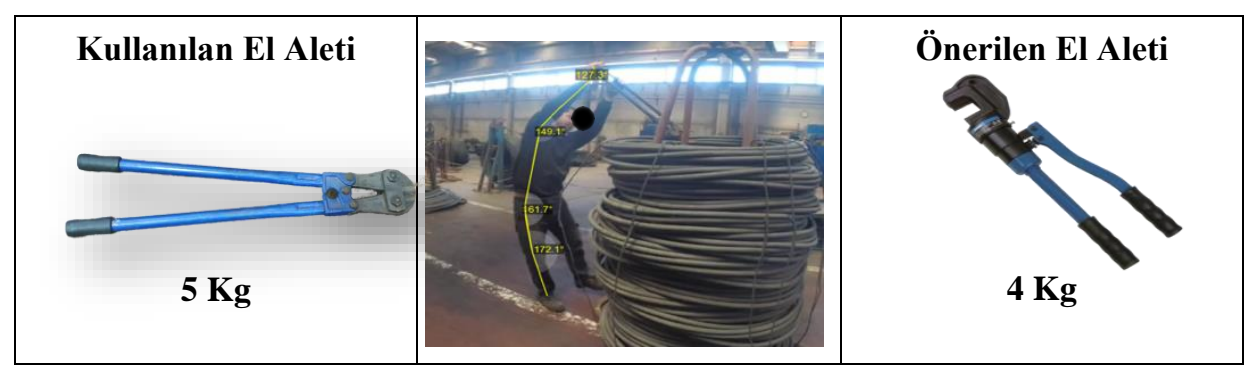

Şekil 12. Tel Bă̆ının Makasla Kesilme İşlemi İyileştirme Önerisi

- Ergonomik risk seviyesinin yüksek çıktı̆̆ diğer bir görev ise 1000 'lik makinedeki hadde çapına uygun telin doğrultulması işlemidir. $\mathrm{Bu}$ işlemde çalışan bir boru yardımıyla 3-5 metrelik teli doğrultmaya çalışırken yüksek efor sarf etmektedir. Bununla birlikte tel doğrultma sırasında çalışanın kolu genellikle omuz hizasından yüksekte durmaktadır. Bütün bunlar risk seviyesini artırmaktadır. İyileştirme önerisine ait görsel Şekil 13'de verilmiş̧ir. Doğrultma işleminin doğrultma makinesi yardımıyla yapılması çalışan üzerindeki riski en aza indireceği ve görevin daha kısa sürede gerçekleştirileceği düşünülmektedir. 


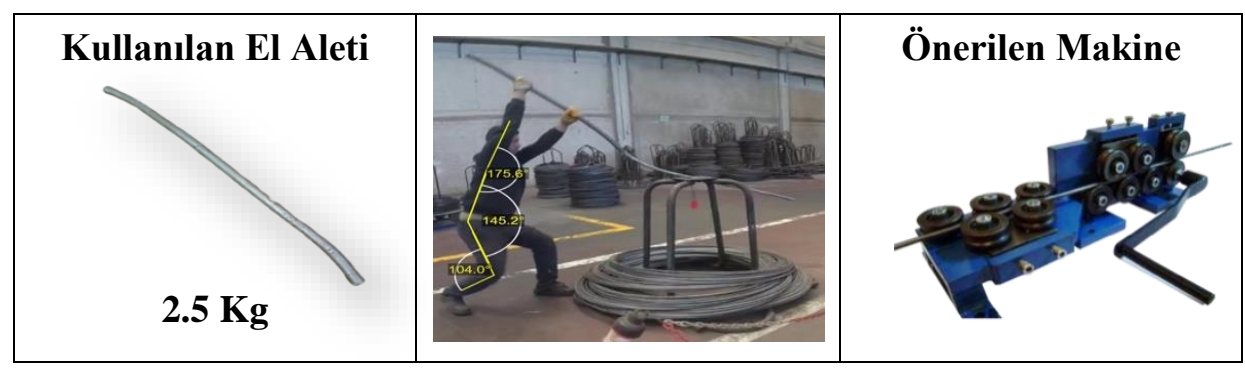

Şekil 13. Hadde Çapına Uygun Telin Doğrultma İşlemi İyileştirme Önerisi

- Başka bir yüksek risk 1000'lik makinedeki telin ucuna kaynak yapılması işleminde görülmektedir. Değerlendirmede ergonomik riski artıran unsurlar, telin kaynak yapılmasında ihtiyaç duyulan anlık güç artışı, çalışanın 1 dakikadan uzun süre yüksek düzeyde kuvvet uygulaması, bacağın ve belin bükük olmasıdır. Riski artıran unsurların başında kaynak esnasındaki güç gereksinimine bağlı olarak çalışanın uygun olmayan pozisyonlara maruz kalması dikkati çekmektedir. Makine üzerine tam otomasyonu sağlayacak bir düzenek geliştirilmesi önerilmektedir. $\mathrm{Bu}$ sayede çalışanın fiziksel gücüne ihtiyacın ortadan kalkacağ1, ergonomik riskin minimum seviyeye ineceği ve sürecin hızlanacağı düşünülmektedir.

- Yüksek risk seviyesi grubunda yer alan diğer bir görev, filmaşin ucunun doğrultulmasıdır. 1000'lik makinedeki süreçlerden olan bu işlem yüksek düzeyde güç gerektirdiği için bir çalışan yeterli olmayıp iki çalışanın çabasıyla tamamlanabilmektedir. Bu işlem için dikkat çekici unsurlar, doğrultma işi için ihtiyaç duyulan anlık güç artış1, çalışanların yüksek düzeyde kuvvet uygulaması, belin ve bacağın bükük olmasıdır. Bütün doğrultma işlemlerinin doğrultma makinesi yardımıyla yapılması çalışan üzerindeki riski en aza indireceği ve işlemin daha hızlı bir şekilde gerçekleştirilebileceği düşünülmektedir.

- Hurda tellerinin toplanması işleminde çalışanın yerdeki telleri toplamak için sürekli eğilip kalkması, kas ve iskelet sisteminde yük oluşturmaktadır. $\mathrm{Bu}$ işlemin manyetik mıknatıslı tel toplama aleti ile yapılması çalışanın kas ve iskelet sistemi üzerindeki yükünü azaltacağ1 düşünülmektedir. İyileştirme önerisine ait görsel Şekil 14'te verilmiştir.

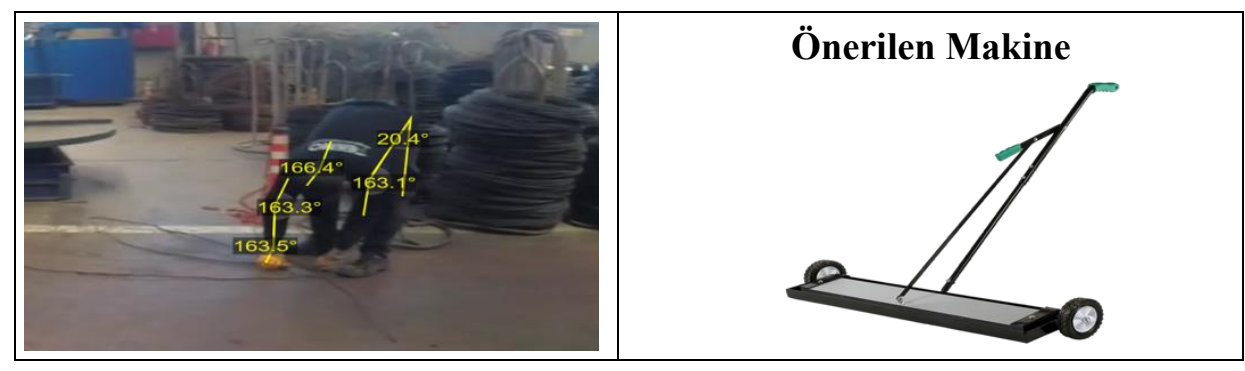

Şekil 14. Hurda Tellerinin Toplanması İşlemi İyileştirme Önerisi

- $\quad$ Risk seviyesinin yüksek olduğu diğer bir görev ise 6 kafa makinesindeki dolan sepetin transpaletle kaldırılması işlemidir. İşlem her ne kadar transpalet ile yapılıyor olsa da çalışan transpalet kolunu basarken eğilip kalkmakta ve üzerindeki yükü kaldırabilmek için oldukça zorlanmaktadır. İnsan gücüyle çalışan transpaletin yerine elektrikli bir transpaletin kullanılması çalışanın üzerindeki riski minimum seviyeye indireceği düşünülmektedir. Ayrıca elektrikli transpaletteki baskül özelliği sayesinde dolmuş sepet ağırlığ1 kolayca ölçülebileceği için çalışanın vincin ucuna takılan $12,5 \mathrm{~kg}$ ağırlığındaki kantar başlığını taşıma ve kaldırma işlemini ortadan kaldıracaktır. $\mathrm{Bu}$ sayede sürecin kısalacağ 1 ve çalışan üzerindeki zorlanmanın en aza ineceği düşünülmektedir. İyileştirme önerisine ait görsel Şekil 15 'te verilmiştir.

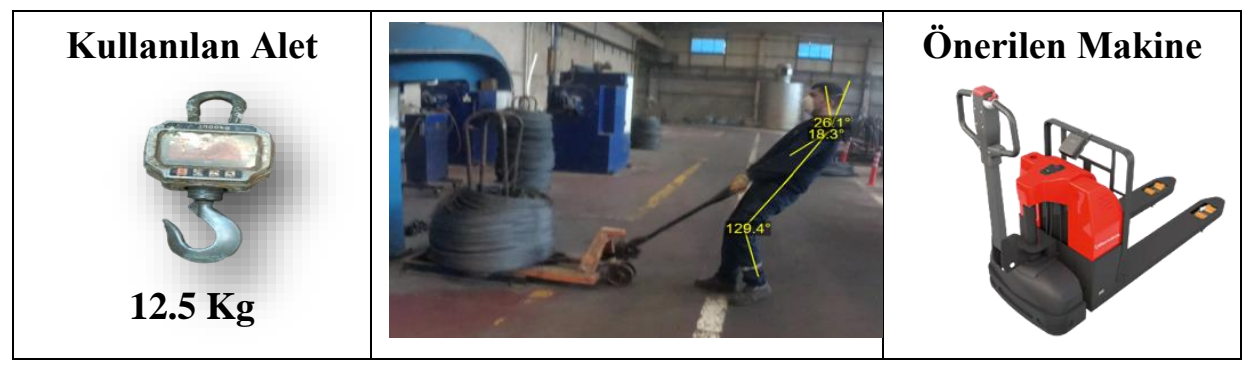

Şekil 15. Dolan Sepetin Transpaletle Kaldırılması İşlemi İyileştirme Önerisi

- Yüksek risk grubunda yer alan başka bir görev, dolmuş sepetin kafa altından çekilmesidir. Son çekim makinesindeki süreçlerden olan bu işlemde çalışan sepeti hareket ettirebilmek için aşırı güç uygulamak zorunda kalmaktadır. $\mathrm{Bu}$ görev için elektrikli bant sisteminin yapılması önerilmektedir. Bu uygulama ile çalışanın çekme sırasındaki çabasının ve zorlanmasının ortadan kalkacağı düşünülmektedir. 
- $\quad$ Risk seviyesi yüksek çıkan diğer görevler ise genellikle çalışanın uygunsuz pozisyonda iş yapmasından kaynaklanmaktadır. Çalışanlar doğru vücut duruşları hakkında bilgiye sahip olmadıklarında görevleri uygun olmayan pozisyonda gerçekleştirebilmektedir. Bu noktada çalışanların doğru çalışma duruşları hakkında bilgilendirilmesinin bu görevlerdeki riskleri azaltacağ düşünülmektedir.

- $\quad$ Risk seviyesi çok yüksek çıkan görevler 1000'lik makine üzerinde yoğunlaşmaktadır. Risk seviyesinin diğer makinelere göre yüksek çıkmasının temel nedeni 1000'lik makinedeki işlenen tellerin çap kalınlığının daha fazla olmasıdır. Tel çapı kalınlaştıkça kesme, kaynatma ve taşlama işlemleri çalışanları daha fazla zorlamaktadır. Bu durum özellikle 1000'lik makine çalışanlarının diğer makine çalışanlarına kıyasla daha fazla riske maruz kalmasına neden olmaktadır. Makine sayısının çok fazla olmadığı tel çekme bölümündeki personelin makinelerde dönüşümlü çalışması önerilmektedir. Bu rotasyon sayesinde çalışanların maruz kaldıkları farklı seviyedeki risklerin ortadan kaldırılabileceği ve çalışanların aynı işi yapabilme becerisinin artacağı düşünülmektedir. Bu uygulama ile tel çekme bölümündeki çalışanların aynı işlerdeki performans karşılaştırmasının da yapılabileceği düşünülmektedir.

- Çok yüksek ve yüksek risk grubunda yer alan görevlerin toplam işlem süreleri, ortalama $16 \mathrm{dk} 2 \mathrm{sn}$ sürmektedir. İyileştirme önerilerine uyulması sonucunda işlem sürelerinde $\% 50$ oranında kısalmanın olacağı ön görülmektedir. $\mathrm{Bu}$ durumun gerçekleşmesi halinde çok yüksek ve yüksek risk kategorisindeki görevlerin sürelerinde, ortalama $8 \mathrm{dk}$ kısalma meydana gelecektir. Günde 3 vardiya çalışan fabrikada, 15 defa bu süreçlerin tekrar ettiği varsayıldığında, toplam işlem süresi günlük ortalama $120 \mathrm{dk}$ kısalacaktır. Yıllık bazda bakıldığında ise tel çekme bölümünde yaklaşık 600 saatlik bir çalışma zamanı kazanılacağını ifade etmek mümkündür. $\mathrm{Bu}$ hesaplamadan hareketle, çalışmanın, kapasite kullanım oranı \%20 olan tel çekme bölümünde verimliliğe ciddi oranda katkı sağlayacağı düşünülmektedir.

\section{Sonuç}

$\mathrm{Bu}$ çalışmada imalat işletmelerinin üretim süreçlerinde ortaya çıkabilecek risklerin belirlenmesine yönelik bir uygulama modeli geliştirilmesi amaçlanmıştır. Bu kapsamda cıvata üretimi yapan bir fabrikada örnek uygulama gerçekleştirilmiştir. Uygulama sürecinde mevcut yöntemler dikkate alınarak değerlendirme formatı geliştirilmiştir. $\mathrm{Bu}$ yanıyla çalışmanın özgünlüğünün artırılması amaçlanmıştır. Geliştirilen format çerçevesinde elde edilen veriler analiz edilerek riskli operasyonların değerlendirilmesi yapılmıştır.

Değerlendirme sürecinde REBA, RULA ve QEC olmak üzere üç farklı yöntem kullanılmıştır. REBA ve RULA yöntemleri öncelikli olarak uygulanmış olup bu yöntemlerin hareketlerin tekrar sayısını dikkate almadığından dolayı ek olarak QEC yöntemiyle de analizler gerçekleştirilmiştir. Riskli olabilecek bütün görevlere bu üç yöntem uygulanmıştır. Sonrasında görevler için her bir yöntemle elde edilen risk seviyelerinin tek bir risk seviyesine dönüştürülmesi şeklinde bir yol izlenmiştir. Dönüştürmede risk seviyesi sonuçlarına göre üç yöntemden en az ikisinin işaret ettiği risk seviyesi veya ortalama risk seviyesi dikkate alınmıştır. Risk seviyesi çok yüksek veya yüksek çıkan görevler için iyileştirme önerileri sunulmuştur.
Geliştirilen uygulama formatının en önemli özelliklerinden birisi de süreçlerin video kaydına alınarak analizlerin yapılmasıdır. $\mathrm{Bu}$ konu üzerine yapılan çalışmaların büyük çoğunluğunda analizler fotoğrafa dayalı veriler üzerinden yapılmıştır. Fotoğraf çekilme esnasında çalışanlarda çevresel koşullara ve kısa çevrim sürelerine bağlı olarak baskı artabileceği için veri güvenilirliği azalabilmektedir. Dolayısıyla fotoğraflama tekniği ile toplanan verilerin analizleri gözlemciyi yanıltabilmektedir. Gözleme dayalı fotoğraflama yöntemindeki bu eksiklik dikkate alınarak süreçler aksiyon kameralarıyla farklı zamanlarda birçok kez video kaydına alınmıştır. Ayrıca ölçümden kaynaklanan hataları ortadan kaldırılabilmek için çalışanların duruş pozisyonlarına ilişkin açı değerleri Dartfish paket programı ile hesaplanmıştır.

Tel çekme bölümü, fabrikada emeğin en yoğun olduğu ve çalışanların fiziksel olarak en çok zorlandığı bölüm olarak düşünüldüğü için tercih edilmiştir. Yine aynı sebeple tel çekme bölümünde emeğin yoğun olduğu makineler incelemeye alınmıştır. Araştırmanın bulguları çalışanlar aynı bölümde benzer işleri yapsalar bile kullanılan el aletlerinden, duruş pozisyonlarından, iş yapış biçimlerinden ve makine farklılığından kaynaklı farklı seviyelerde riske maruz kaldıklarını göstermektedir. $\mathrm{Bu}$ farklılıklar çalışanların performanslarını, motivasyonlarını ve verimliliklerini olumsuz yönde etkileyebilmektedir. Çalışanların performanslarını motivasyonunu ve verimliliğini etkileyecek her şey aynı zamanda işletmenin genel performansını da etkileyeceği için bu farklılıkların ortadan kaldırılması hem çalışan hem de işletme açısından büyük önem taşımaktadır.

Hesaplamalar sonucunda görevlerin \%43’ünün orta risk, \%22'sinin yüksek risk, \%22'sinin düşük risk ve \%13'ünün çok yüksek risk grubunda olduğu görülmüştür. Görevlerin toplamda $\% 35$ 'i çok yüksek ve yüksek risk grubunda yer almaktadır. Bu sonuç söz konusu görevlerin kısa süre içerisinde veya acilen iyileştirilmesi gerektiğine işaret etmektedir. Bu iyileştirmelerin gerçekleştirilebilmesi için üst yönetim ve çalışanların iyileştirmeleri kabullenmesi ve sahiplenmesi gerekmektedir. Ayrıca uygulama formatının fabrikanın diğer bölümlerinde de hayata geçirilmesi bu konuda bir örgüt kültürünün oluşmasına da katkı sağlayacaktır.

Çalışma sonucunda görevlerin risk seviyesine ilişkin bu bulgular literatürde yer alan risk değerlendirme çalışma sonuçlarına göre farklılık arz etmektedir (Atıcı vd., 2015; Ericsson vd., 2012; İnalçuk, 2019; Koç \& Testik, 2016; Neşeli, 2016; Rahman, 2014; Rahmani vd., 2020). Bu farklılığın sektörden, çalışandan, yönetimden veya fabrikanın sahip olduğu üretim teknolojisinden kaynaklandığı düşünülmektedir.

İyileştirme önerilerine uyulması sonucunda öncelikle tel çekme bölümündeki çalışanlarda iş yapmaya bağlı zorlanmaların azalacağı, çalışanların iş güvenliği ve yaşam kalitesinin iyileşeceği düşünülmektedir. Sonrasında ise bu önerilerin işlem sürelerini kısaltmasına ve çalışanlarda rahatsızlığın daha az yaşanmasına katkı sağlamasına bağlı olarak verimlilikte artış sağlayacağı düşünülmektedir. Tel çekme bölümünde ulaşılacak olumlu faydalar diğer bölümler ve hatta diğer fabrikalar için örnek teşkil edebilecektir. Bu çalışmada kullanılan yöntem ve metot diğer bölüm ve fabrikalarda da sistematik bir şekilde kullanılabilecektir. Çalışma kapsamında sistematik olarak geliştirilen uygulama modeli bilimsel birikime, bölgesel ve ulusal ekonomiye katkı sağlayacağı düşünülmektedir. İyileştirme 
önerilerinin hayata geçirilmesinde yalın üretim tekniklerinin kullanılması bir başka araştırma konusu olarak belirlenmiştir.

\section{Kaynakça}

Alici, H., Ulusu Atıc1, H., \& Gündüz, T. (2017). Mobilya Sektöründe Pnömatik Zımbalama ve Vidalama İşlerinin Ergonomik Risk Değerlendirmesi. Çukurova Üniversitesi Mühendislik Mimarlık Fakültesi Dergisi, 32(4), 211-225.

Amell, T., \& Kumar, S. (2001). Work-Related Musculoskeletal Disorders: Design as a Prevention Strategy. A Review. Journal of occupational rehabilitation, 11(4), 255-265.

Andreas, G.-W. J., \& Johanssons, E. (2018). Observational Methods for Assessing Ergonomic Risks for Work-Related Musculoskeletal Disorders. A Scoping Review. Revista Ciencias de la Salud, 16(SPE), 8-38.

Atıc1, H., Gönen, D., \& Oral, A. (2015). Çalışanlarda Zorlanmaya Neden Olan Duruşların REBA Yöntemi ile Ergonomik Analizi. Mühendislik Bilimleri ve Tasarım Dergisi, 3(3), 239-244.

Avc1, K., \& Pala, K. (2004). Uludağ Üniversitesi T1p Fakültesinde Çalışan Araştırma Görevlisi ve Uzman Doktorların Yaşam Kalitesinin Değerlendirilmesi. Uludağ Üniversitesi Tıp Fakültesi Dergisi, 30(2), 81-85.

Bernacki, E. J., Guidera, J. A., Schaefer, J. A., Lavin, R. A., \& Tsai, S. P. (1999). An Ergonomics Program Designed to Reduce the Incidence of Upper Extremity Work Related Musculoskeletal Disorders. Journal of Occupational and Environmental Medicine, 41(12), 1032-1041.

Bilir, N. (2007). Mesleksel Kas İskelet Sistemi Hastalıkları. İş Sağlı̆̆l ve Güvenliği Dergisi, 34(7), 10-13.

Boles, M., Pelletier, B., \& Lynch, W. (2004). The Relationship Between Health Risks and Work Productivity. Journal of Occupational and Environmental Medicine, 46(7), 737745 .

Bulduk, E. Ö., Bulduk, S., Süren, T., \& Ovalı, F. (2014). Assessing Exposure to Risk Factors for Work-Related Musculoskeletal Disorders Using Quick Exposure Check (QEC) in Taxi Drivers. International Journal of Industrial Ergonomics, 44(6), 817-820.

Burdorf, A., \& Van Der Beek, A. (1999). Exposure Assessment Strategies for Work-Related Risk Factors for Musculoskeletal Disorders. Scandinavian journal of work, environment \& health, 25(4), 25-30.

Burton, W. N., Conti, D. J., Chen, C.-Y., Schultz, A. B., \& Edington, D. W. (1999). The Role of Health Risk Factors and Disease on Worker Productivity. Journal of occupational and environmental medicine, 41(10), 863877.

Canadian Centre for Occupational Health and Safety. (2014). Work-related Musculoskeletal Disorders (WMSDs) : OSH Answers. 26 Ocak 2020 Tarihinde, https://www.ccohs.ca/oshanswers/diseases/rmirsi.html adresinden erişildi

David, G. C. (2005). Ergonomic Methods for Assessing Exposure to Risk Factors for Work-Related Musculoskeletal Disorders. Occupational Medicine, 55(3),
190-199.

David, G., Woods, V., Li, G., \& Buckle, P. (2008). The Development of the Quick Exposure Check (QEC) for Assessing Exposure to Risk Factors for Work-Related Musculoskeletal Disorders. Applied Ergonomics, 39(1), $57-69$.

Deste, M., \& Sever, S. (2019). İmalat İşletmelerinde Ergonomik Risk Değerlendirme Yöntemleri Üzerine Bibliyometrik Bir Analiz. Ekev Akademi Dergisi, 209-224.

E-Kart | İSG (İş Sağlığı Güvenliği ). (y.y.). 05 Kasım 2019 tarihinde, https://www.ekart.com.tr/ISG.aspx adresinden erişildi.

Eklund, J. A. E. (1995). Relationships between ergonomics and quality in assembly work. Applied Ergonomics, 26(1), 1520 .

Ericsson, P., Björklund, M., \& Wahlström, J. (2012). Exposure Assessment in Different Occupational Groups at a Hospital Using Quick Exposure Check (QEC)-A Pilot Study. Work, 41(Supplement 1), 5718-5720.

Esen, H., \& Fiğlali, N. (2013). Çalışma Duruşu Analiz Yöntemleri ve Çalışma Duruşunun Kas-İskelet Sistemi Rahatsızlıklarına Etkileri. SA ̈U Fen Bilimleri Dergisi, 17(1), 41-51.

Foye, P. M., Cianca, J. C., \& Prather, H. (2002). Cumulative Trauma Disorders of the Upper Limb in Computer Users. Archives of Physical Medicine and Rehabilitation, 83, S12-S15.

Grossmeier, J., Mangen, D. J., Terry, P. E., \& HaglundHowieson, L. (2015). Health Risk Change as a Predictor of Productivity Change. Journal of occupational and environmental medicine, 57(4), 347-354.

İnalçuk, E. (2019). Investigation of Ergonomic Risks in Manufacturing Sector Using Quick Exposure Check Method. (Yayımlanmamış yüksek lisans tezi). Orta Doğu Teknik Üniversitesi Fen Bilimleri Enstitüsü İş Sağlığı ve Güvenliği Ana Bilim Dalı, Ankara.

Karwowski, W., \& Gavriel, S. (1998). Ergonomics in Manufacturing.

Koç, S., \& Testik, Ö. M. (2016). Mobilya Sektöründe Yaşanan Kas-İskelet Sistemi Risklerinin Farklı Değerlendirme Metotlari ile İncelenmesi ve Minimizasyonu. Endüstri Mühendisliği Dergisi, 27(2), 2-27.

Küçük, O., Özbek, A., \& Küçük, N. (2015). Sağlık Sorunları Sebebiyle İşgücü Kaybının Örgüt Performansına Etkisi Üzerine Bir Çalışma. Atatürk Üniversitesi Sosyal Bilimler Enstitüsü Dergisi, 19(2), 311-332.

Lasota, A. M. (2014). A REBA-Based Analaysis of Packers Workload: A Case Study. Scientific Journal of Logistics, 10(1), 87-95.

Li, G., \& Buckle, P. (2004). Quick Exposure Checklist (QEC) for the Assessment of Workplace Risks for Work-Related Musculoskeletal Disorders (WMSDs). Içinde Handbook of human factors and ergonomics methods (ss. 74-85). CRC Press.

Li, X., Gül, M., \& Al-Hussein, M. (2019). An Improved Physical 
Demand Analysis Framework Based on Ergonomic Risk Assessment Tools for the Manufacturing Industry. International Journal of Industrial Ergonomics, 70, 58-69.

Massaccesi, M., Pagnotta, A., Soccetti, A., Masali, M., Masiero, C., \& Greco, F. (2003). Investigation of Work-Related Disorders in Truck Drivers Using RULA Method. Applied ergonomics, 34(4), 303-307.

McAtamney, L., \& Corlett, E. N. (1993). RULA: A Survey Method for the Investigation of Work-Related Upper Limb Disorders. Applied ergonomics, 24(2), 91-99.

McAtamney, L., \& Hignett, S. (2000). Rapid Entire Body Assessment(REBA). Applied Ergonomics, 31, 201-205.

Middlesworth, M. (2019). A Step-by-Step Guide to the RULA Assessment Tool. 13 Mart 2020 tarihinde, https://ergoplus.com/rula-assessment-tool-guide/ adresinden erişildi.

Neşeli, C. (2016). Ergonomik Risk Analizi Yöntemlerinin Karşılaştırılması ve Bir Kalıp Firmasında Uygulanması. (Yayımlanmamış yüksek lisans tezi). İzmir Katip Çelebi Üniversitesi Fen Bilimleri Enstitüsü İş Sağlığı ve Güvenliği Ana Bilim Dalı, İzmir.

Özcan, E. (2011). İş Yerinde Ergonomik Risklerin Değerlendirilmesi ve Hizlı Maruziyet Değerlendirme (HMD) Yöntemi. Ergonomics Risk Assessment and Quick Exposure Check (QEC)., (616), 86-89.

Özcan, E., \& Kesiktaş, N. (2007). Mesleki Kas İskelet Hastalıklarından Korunma ve Ergonomi. İş Să̆lı̆ $l$ ve Güvenliği Dergisi, 34(7), 6-9.

Ozcan, E., Kesiktas, N., Alptekin, K., \& Ozcan, E. E. (2008). The Reliability of Turkish Translation of Quick Exposure Check (QEC) for Risk Assessment of Work Related Musculoskeletal Disorders. Journal of Back and Musculoskeletal Rehabilitation, 21(1), 51-56.

Özel, E., \& Çetik, O. (2010). Mesleki Görevlerin Ergonomik Analizinde Kullanılan Araçlar ve Bir Uygulama Örneği. Dumlupınar Üniversitesi Fen Bilimleri Enstitüsü Dergisi, $22,41-56$.

Öztürk, N. Ş., \& Akbulut, Y. (2011). Hemşirelerin İş Gücü Verimliliğini Etkileyen Örgütsel Faktörler Konusundaki Tutumlarının Belirlenmesi. Ankara Sağlık Hizmetleri Dergisi, 10(1), 19-30.

Rahma, R. A. A., \& Faiz, I. (2019). Work Posture Analysis of Gamelan Craft Center Workers Using Quick Methods of Ergonomic Risk Assessment. Journal of Physics: Conference Series, 1381(1), 12027. IOP Publishing.

Rahman, C. M. (2014). Study and Analysis of Work Postures of Workers Working in a Ceramic Industry Through Rapid Upper Limb Assessment (RULA). International Journal of Engineering, 5(3), 8269.

Rahmani, R., Shahnavazi, S., Fazli, B., \& Ghasemi, F. (2020). Ergonomic Assessment of Musculoskeletal Disorders Risk in a Cement Factory Workers Using QEC Teqnique. Pajouhan Scientific Journal, 18(2), 83-90.

Riedel, J. E., Lynch, W., Baase, C., Hymel, P., \& Peterson, K. W. (2001). The Effect of Disease Prevention and Health Promotion on Workplace Productivity: A Literature Review. American Journal of Health Promotion, 15(3),
167-191.

Sağıroğlu, H., Coşkun, B., \& Erginel, N. (2015). REBA ile Bir Üretim Hattındaki İş İstasyonlarının Ergonomik Risk Analizi. Süleyman Demirel Üniversitesi Mühendislik Bilimleri ve Tasarım Dergisi, 3(3), 339-345.

Savitri, A., Mulyati, G. T., \& Aziz, I. W. F. (2012). Evaluation of Working Postures at a Garden Maintenance Service to Reduce Musculoskeletal Disorder Risk (A case study of PT. Dewijaya Agrigemilang Jakarta). Agroindustrial Journal, 1(1), 21-27.

Sencer, M., Eldem, C., Top, N., \& Şahin, İ. (2019). RULA Yöntemi Kullanarak Şehir İçi Otobüslerdeki Havalandırma Pencerelerinin Ergonomik Analizi. International Symposium on Automotive Science and Technology. Ankara.

Sevimli, M., Atıcı Ulusu, H., \& Gündüz, T. (2018). Pirinç Paketleme İşinde Çalışanların Çalışma Koşullarının Ergonomik Risk Analizleri ile Geliştirilmesi. Balıkesir Üniversitesi Fen Bilimleri Enstitüsü Dergisi, 20(1), 38-54.

SGK. (2019). SGK 2017. 20 Aralık 2019 tarihinde , http://www.sgk.gov.tr/wps/portal/sgk/tr/kurumsal/istatistik/ sgk_istatistik_yilliklari adresinden erişildi.

Silverstein, B., \& Clark, R. (2004). Interventions to Reduce Work-Related Musculoskeletal Disorders. Journal of Electromyography and Kinesiology.

Sukadarin, E. H., Md Deros, B., Ghani, J. A., Ismail, A. R., Mokhtar, M. M., \& Mohamad, D. (2013). Investigation of Ergonomics Risk Factors for Musculoskeletal Disorders among Oil Palm Workers Using Quick Exposure Check (QEC). Advanced Engineering Forum, 10, 103-109.

Testa, M. A., \& Simonson, D. C. (1996). Assessment of QualityOf-Life Outcomes. New England journal of medicine, 334(13), 835-840.

Ünver Okan, S., \& Kaya, A. (2015). Orman Fiidanlıklarında Fidan Repikaj İşlerinde Çalışma Duruşlarının REBA Yöntemi İle Analizi. Süleyman Demirel Üniversitesi Mühendislik Bilimleri ve Tasarım Dergisi, 3(3), 157-163.

Uskun, E., Öztürk, M., Kişioğlu, A. N., \& Sönmez, Y. (2015). Bir Sanayi Sitesinde Küçük Ölçekli İşyerlerindeki Risk Faktörleri ve Yaşam Kalitesi ile İlişkisi. Türkiye Halk Sağlı̆̆ Dergisi, 13(2), 97.

Verbeek, J., Pulliainen, M., \& Kankaanpää, E. (2009). A Systematic Review of Occupational Safety and Health Business Cases. Scandinavian journal of work, environment \& health, 35(6), 403-412.

Village, J., Trask, C., Luong, N., Chow, Y., Johnson, P., Koehoorn, M., \& Teschke, K. (2009). Development and Evaluation of an Observational Back-Exposure Sampling Tool (Back-EST) for Work-Related Back Injury Risk Factors. Applied Ergonomics, 40(3), 538-544. 